\title{
PUBLIC AMENITIES IN RURAL SUBURBAN SETTLEMENTS IN BRATISLAVA'S HINTERLAND
}

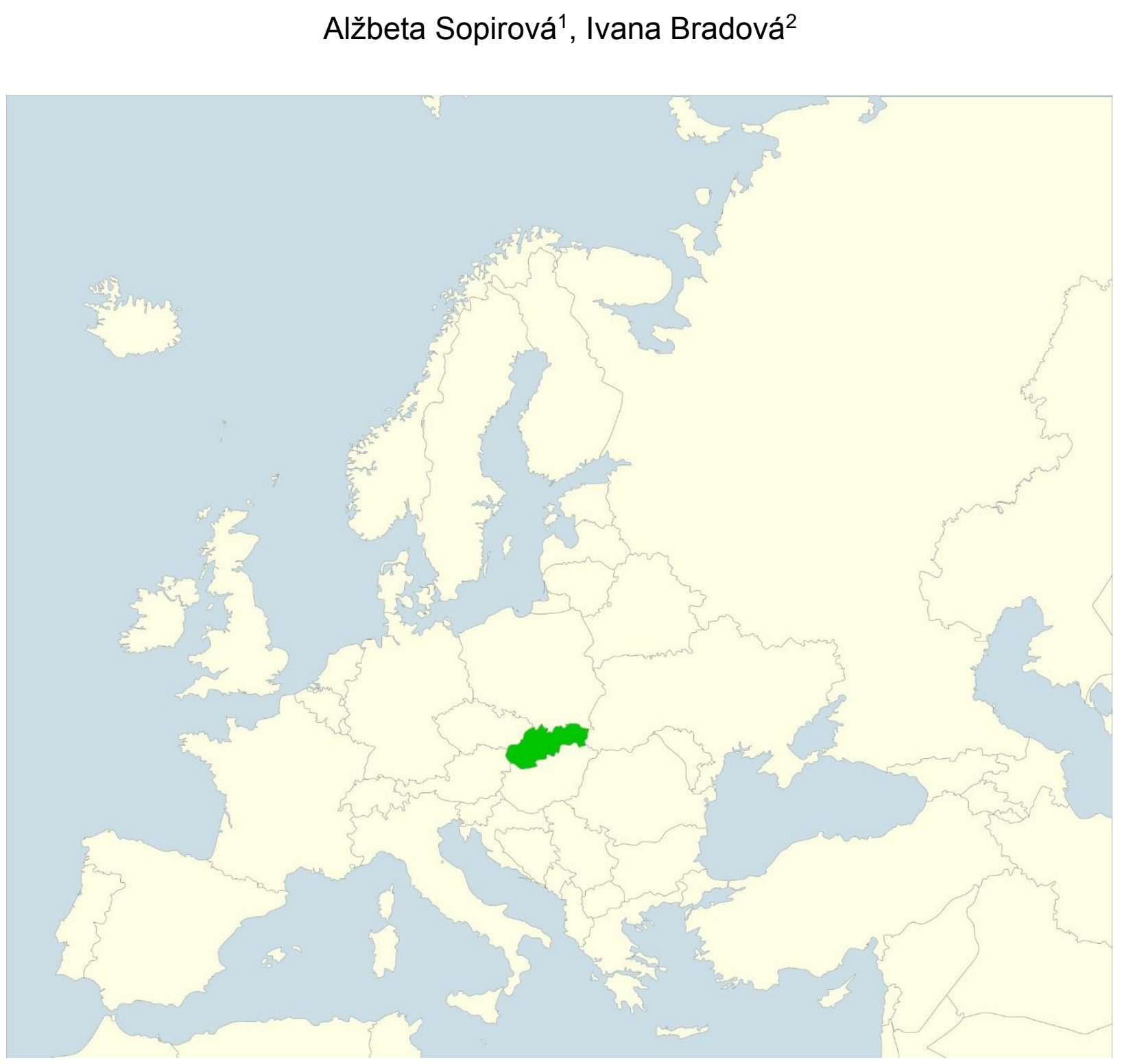

\footnotetext{
1 doc. Ing. arch. Alžbeta Sopirová, PhD., Institute of Urban Design and Planning, Faculty of Architecture Slovak University of Technology in Bratislava, sopirova@fa.stuba.sk; ORCID: 0000-0003-2431-9561

2 Ing. arch. Ivana Bradová, Institute of Urban Design and Planning, Faculty of Architecture Slovak University of Technology in Bratislava, bradova.iva@gmail.com; ORCID: 0000-0003-1782-8202
} 
Abstract: The present paper examines selected urbanistic parameters of public amenities in rural residential areas in the suburban hinterland of Bratislava, which has undergone a rapid development in the past 20 years. In an overall perception of a residential area in terms of its attractivity and vitality, the location, type, structural and technical condition of buildings have a significant influence, together with related public spaces that are indicative of the place's continuity of development, identity, specificity and standard of living. A quantitative comparison of public amenities presents the differences between selected municipalities on the Danube development axis and their causal relationships. This paper suggests the minimum standards of public amenities necessary for a positive identification with a residential area on both the locals' and the visitors' part.

Keywords: residential suburbanisation, public amenities, quantitative indicators, quality of life

Abstrakt: Článok skúma vybrané urbanistické parametre zariadení občianskej vybavenosti vo vidieckych sídlach, ležiacich v suburbanizačnom zázemí Bratislavy, ktoré za ostatných 20 rokov zaznamenali svoj dynamický rozvoj. Výrazný podiel na vnímaní celkového obrazu sídla, jeho atraktivity a vitality, má lokalizácia, druhovost', stavebno-technický stav objektov a s nimi spojené verejné priestory prezentujúce kontinuitu vývoja, identitu, znakovost' a životnú úroveň miesta. Kvantitatívna komparácia zariadení občianskej vybavenosti prezentuje rozdiely medzi vybranými obcami na Dunajskostredskej rozvojovej osi a ich príčinné súvislosti. Príspevok naznačuje minimálne štandardy, ktoré by mali mat' zariadenia občianskej vybavenosti, aby sa obyvatelia aj návštevníci so sídlom pozitívne identifikovali.

Kl'účové slová: rezidenčná suburbanizácia, zariadenia občianskej vybavenosti, kvantitatívne ukazovatele, kvalita života

\section{Introduction}

Suburbanisation has a significant impact on the quality of life in original country regions situated in hinterlands of cities which are being dynamically expanded by new, anonymous housing estates. According to the European Enviroment Agency, suburbanisation is one of the key developmental processes in Europe, and it has a negative impact on the countryside (EEA, 2006). The continuing occupation of fertile land by a carpet grid of family houses results in a loss of the countryside's agricultural character, which directly increases the dependence on food provisions from surrounding regions and accelerates the rate of gradual exhaustion of local natural resources. This trend has become global and caused a number of global changes.

The process of suburbanisation emerged in England in the 18th century and gained traction at the turn of the 19th and 20th centuries. According to the geographers Matlovič and Sedláková (2004), suburbanisation became more pronounced in the USA after the Second World War. It was characterised by areas of family houses arranged according to a regular ground plan, which were built on greenfield sites. In the absence of necessary regulations, this American (bad) dream has affected immense areas. "Within the largest urbanised areas, central cities contained close to 65 per cent of the urbanised populations in the 1950s, which had already reached substantial proportions (35 per cent of urbanised populations) by mid-century." (Nechyba, Walsh, 2004, p. 179).

The onset of suburbanisation in Western Europe since the 1950s did not have such a fierce and spontaneous course, probably due to more stringent legislation as well as local plans, which partly regulated new residential developments (Šveda, 2011). It manifested itself in spatial forms of development of varying intensity on city outskirts; these did not observe compact ground plans of the built-up area. Later, buildings were constructed in the vicinity of primary communications and scattered satellite settlements in agricultural landscape emerged. According to the sociologist Peter Gajdoš, transformations of certain contemporary European settlements are influenced by 
processes and phenomena that take place outside their administrative territory or even outside the borders of the state in which they are located.

In post-socialist countries, this suburbanisation process has been developing since the 1990s. However, publications comparing the course of suburbanisation in these countries do not include Slovakia (e.g. Stanilov, Sýkora, 2014). Economical, social and cultural influences on suburban regions in Slovakia and the Czech Republic have been surveyed by the sociologists Gajdoš (2009), Buchta (2017) and the geographers Matlovič, Sedláková (2004), Šveda (2006), Sýkora, Posová (2011), Repaská, Vilinová, Šolcová (2017) and others. In other periods, the issues of quality of life in suburban country regions are at the forefront; research on this topic from definition to its measurable values has been done by Antonín Vaishar, Lucie Vidovićová, Elisabete Figueiredo (2018). In order to improve quality of life for inhabitants of suburbias, there arises an urgent need to transform the suburbs into sustainable, energetically more efficient forms. These changes are described in detail in the handbook Sprawl Repair Manual by Galina Tachieva, from general regulations to model examples of transformed urban blocks and objects (Tachieva, 2011).

The liberalisation of housing and land prices, the emergence of a market environment, and the demand for quality housing in an attractive environment have in the past 20 years accelerated suburbanisation in Slovakia. This has had consequences such as massive expansion of cities into surrounding settlements and open landscape, calculated occupation of valuable agricultural land by new constructions, movement of inhabitants from cities to the countryside, or daily commuting. According to Matlovič (2004), suburbanisation is a process that depends on the size of a city and its position in the hierarchical structure of the settlement system. This trend in urban development has been reflected in settlements becoming more attractive and economically stable because of convenient transport to the city, but especially because of favourable market prices of land, which is consequently used for construction of buildings. Frequently, extensive development take place without the knowledge of actual needs and requirements of the community, including infrastructure.

The suburban zone of Bratislava is impacted by unrestrained construction of new residential units, which are realised without comprehensive planned regulation. Spearheaded by investors and developers, new areas are being taken, the ownership of which is economically valuable and available. These players in the real estate market often initiate, interpret and realise the transformation of an area, while only pursuing their private interests. This is especially dangerous when we consider that in the current market economy, an increase in key amenities is not automatically guaranteed to occur together with an increase in population (it concerns mainly less cost-effective or non-profit-making amenities such as primary schools, kindergartens, parks and the likes) (Görner 2017:53-54). Consequently, monofunctional residential zones marked by commercial activities, whose main motivation is the creation of "profit", are emerging. The real estate market is oversaturated by available areas; supply exceeds demand; developers have the luxury of choice, while municipalities must try to attract them. The available potential of a municipality should be aligned with the social entitlements related to its use, i.e. the development should be controlled, and the restoration of available values should not exceed the acceptable limit states in accordance with the principles of sustainable development of a territory. "A gradual implantation of new features and acceptable architectural forms into the territory of the settlement, while preserving the original urban texture and functional interconnections, can create a rich and diverse environment that we perceive as a valuable urban structure overall." (Sopirová, 2011: 58)

The problem with new residential structures lies not only in their quantity but also their quality. "[People are] trying to escape from the dynamic urban environment to quieter and more natural rural environment which is paradoxically built without any rules or conception." (Sopirova et al., 2017: 544)

From the perspective of sustainability, these solutions are not in line with contemporary urbanistic theories. Many authors (Baše, 2006; Hnilička, 2012; Ouředníček et al., 2013, Görner 2017...) point to the great importance of complexity in residential environment, with an emphasis on the presence of public amenities and public spaces as key elements of sustainability. "One of 
the pillars of the sustainable compact urban structure is its multi-functionality - a good coverage of the amenities within walking distance." (Görner 2017) "In fact, the urban environment in cities comprises not only the population and their characteristics, but also the physical aspects anchored in space by human activities in the long term." (Sýkora, Posová, 2011: 278)

Recently, there has been a shift in the perception of countryside settlements, and it is now considered a higher quality residential environment that should integrate the concepts of modern housing and healthy environment. Therefore, there are fundamental questions to be addressed. To what extent do new residential structures "freeload off" of the municipality's original infrastructure? Is a residential environment with an incomplete infrastructure attractive for new residents? New constructions lack an overarching conception of public amenities and public spaces that would provide them with clear localisation and articulation. Original autonomy and self-sufficiency in rural areas have been disrupted. The aim of this study was to investigate localisations and evaluate quantitative parameters of civic amenities in Bratislava's suburbanising rural settlements, in the context of their connection to existing buildings and new residential structures.

\section{Theoretical background}

The complex development of a settlement for a defined design period is reflected in the municipality's territorial plan. However, numerous updates of an applicable local plan in general only focus on areas affected by proposed changes and amendments of the local plan, which lacks in coordination and complexity of the entire settlement's civic and technical infrastructure in changing conditions. The existing practice shows an increasing investor pressure to reclassify available spaces of public amenities as defined by the local plan to another, for example, residential function. More detailed renditions of an urbanist/architectural concept, when projected into a local plan or urbanist sketch, usually address partial problems and requirements of a particular territory only. Thus, many residential areas do not react adequately to an enormous increase in population; on the contrary, they take advantage of existing facilities, the capacitiy of which is frequently insufficient, and are also unsuitable in terms of accessibility as well as structural and technical condition of the buildings. By favouring an increase in density of the urban structure provided by the construction of new residential buildings, the diversity and attractiveness of the area is diminished, employment opportunities and the quantitative indicators of public amenities become unsatisfactory, and thus the quality and standards of habitability and living of the inhabitants deteriorate. "It is a specific aspect of the quality of life, which forms a residential environment; it is connected to the character of conditions which arise in the settlement, their purpose being to meet the needs and interests of the population and their socio-cultural and personal development. On the one hand, there are the objective conditions for a good life; on the other hand, its subjective experience." (Horňák, Rachovská, 2007) Because of suburbanism, the historical continuity of the settlements' development is disrupted, and their specific customs and traditions are gradually disappearing. It is therefore necessary to note that "the presentation of heritage is deeply linked to the notion of sustainable development, as human groups can not develop by denying their past and therefore have to integrate it in the construction of their future" (Bailoni, Edelblutte, Tchékémian, 2012:149). "This brings about a generational discontinuity in settlements' development, a loss of their specificity and uniqueness, and ultimately a disturbance in the sense of belonging and engagement in the original settlement, or when integrating into a new settlement." (Buchta, 2017) Proposals of public amenities lack in management and coordination of development potential of neighbouring municipalities. The projects are treated in isolation instead of taking common action. This has also been pointed out by the urbanists Vítková and Melcerová, who focused on an evaluation of economic indicators in residential areas (Vitková, 2008).

This is reflected not only in housing demands, but according to the sociologist Gajdoša (2002), it is also in overall requirements for economic and spatial options associated with making use of cultural, educational, medical and sports facilities, distribution and functioning of services, as well as the character of social relations etc. 
Among important indicators of the quality of life in the municipality, there are also the options of creating employment opportunities. The myth of declining quality of life in rural areas due to a significantly less developed economy and lesser purchasing power of the population, which does not stimulate the development of small and medium-sized businesses, does not apply to suburban areas in the present. On the contrary, young and middle-aged people migrate there, who manifest higher qualitative indicators and prefer good services. Frequently, these are entrepreneurs and their companies who "provide diverse employment opportunities for individual members of rural households according to their individual capabilities and needs. There is an obvious energisation of some local important persons who become involved in the development of rural economy but also of the life of the rural population. This is a positive motivational behaviour of specific rural businesses and local communities that serve as a social model for their peers." (Buchta, 2016)

The intrusion of newly constructed residential areas into rural settlements results in capacity issues for the latter concerning retail, educational, medical, social and cultural amenities as well as in continuing daily commute to the city. The proposed starting point for improvement of the unsatisfactory structure and quantitative requirements for retail amenities is a construction of new multipurpose facilities on the edge of the built-up area. However, its placement is problematic in terms of accessibility: the prominence of passenger vehicles puts local communications under excessive strain.

The dependence of personal vehicle traffic on population density was examined by Peter Newman and Jeffrey Kenworthy (1989) and Hnilička (2005); both studies concluded that in order for public transportation to work efficiently, population density of a settlement should be 50100 persons per hectare. On average, a surveyed sample area covered 157.95 ha (sum of the built-up area and completed development plans) and counted 2338 inhabitants, i.e. a population density of only 14.8 persons per hectare, meaning a complete dependence on private transportation. This also proportionately increases the demands on static traffic. "Low density of buildings in an urban sprawl has a marked negative impact on the quality of housing. It limits an overall sustainability of the region and impedes the establishment of quality public spaces." (Hnilička, 2005, p. 69). In the public space, mostly areas of static traffic prevail. For the purposes of social activities, however, interior spaces of multipurpose objects - passages, galleries, sunrooms - are typically used. Typological features characteristic of urban retail facilities are introduced into the rural environment, while each type of amenity is frequently integrated with others (e.g. shop - nursery). Due to the absence of some facilities, private nurseries, kindergartens, specialised clinics, fitness centres etc. are established, even though in the past they were not generally utilised by the community. "Our homes in the countryside are changing into a commercial wasteland." (Hron, 1999).
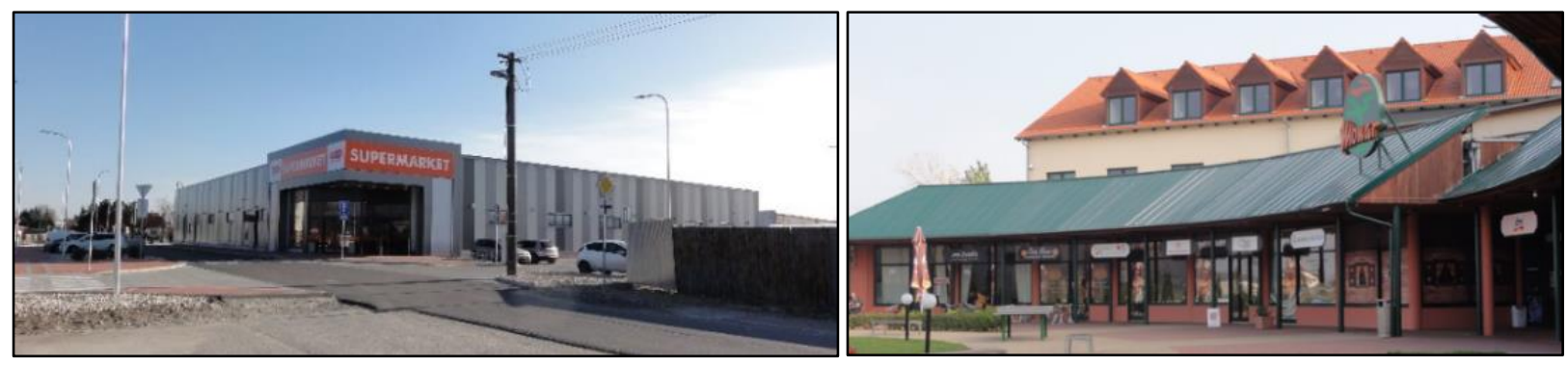

Fig 1. Chorvátsky Grob - shopping centre Monari (Archinex - Ing.arch. Neheš). Credit: A.Sopirová, 2013 


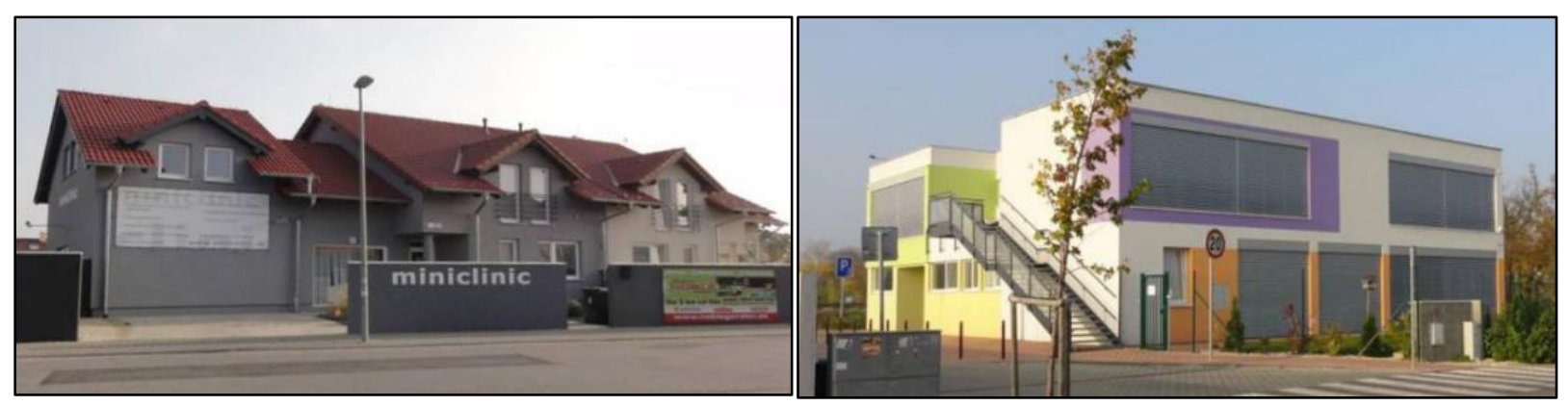

Fig 2,3. Chorvátsky Grob, the Čierna voda area - private amenities (kindergarten, clinic). Credit: A. Sopirová, 2013

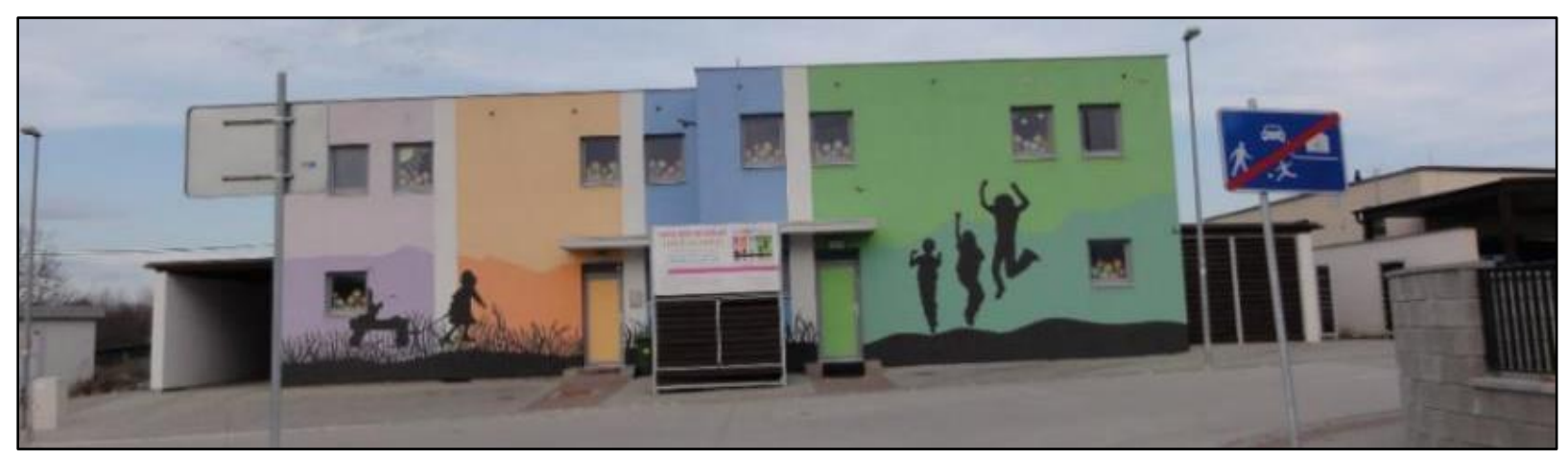

Fig 4. This modular kindergarten building in Ivanka on Danube represents a quick and efficient solution of insufficient capacity of educational facilities in new residential zones. Credit: A. Sopirová, 2013

\section{Methodology}

Prior to the study, the following hypotheses were established:

a) It was assumed newly constructed residential areas in suburban rural settlements within the Bratislava hinterland were parasitising in existing public amenities situated predominantly within a municipality's original structure.

b) It was assumed existing public amenities in suburban rural settlements within the Bratislava hinterland were sufficient in terms of capacity and type.

The research was conducted in three phases:

Stage 1: Selection of a sample territory. The research follows up on a previous examination of the area with the purpose of a quantitative evaluation of public spaces. In the current stage, the research covers the same sample territory - eight rural settlements in the suburban parts of the city of Bratislava on the Danube development axis. Following methods were used: field survey, evaluation of available resources: statistical data, map data and local plan.

Stage 2: Evaluation of predefined indicators: location, type, commuting distance, percentage taken in the settlement, and public amenities area per capita. There were following methods used: Quantitative and qualitative assessment of civic amenities in sample rural settlements.

Stage 3: Comparison of results gathered in the second stage with generally applicable recommendations in the methodological guide "Minimum Standards of Public Amenities in a Municipality." (AŽ Projekt s.r.o., 2010). The methodological manual provides a basis and a tool for local plan authors. It contains obligatory and recommended parameters of municipal amenities, a general typology of public amenities, as well as instructions for their concentration and hierarchy. Comparison, logical methods were used.

In rural settlements, the qualitative aspects of providing public amenities should also be considered besides the quantitative parameters. The qualitative parameters will be the subject of a follow-up research; therefore, they are not covered in this article. 


\section{Results and discussion}

\subsection{Spatial delimitation of subject matter}

The Bratislava agglomeration, which has approximately 680,000 inhabitants, ranks among Slovakia's most economically developed areas; at the same time, however, it also among the most exposed ones in terms of new investments. The development is taking place alongside major transport corridors and residential development axes. The research involves eight rural settlements (Rovinka, Dunajská Lužná, Kalinkovo, Hamuliakovo, Miloslavov, Hviezdoslavov, Kvetoslavov, and Hubice) on the Dunajská streda residential development axis, which during the last twenty years recorded the most significant growth in residential function and in the number of new inhabitants (Figure 5). The surveyed municipalities recorded an enormous increase in population from 149.5\% (Kalinkovo) to 453\% (Hviezdoslavov) compared to 1996 (Figure 5) ), i.e. an annual percentage increase of $12.3 \%$. "According to sociologists, an annual increase of $3 \%$ of inhabitants per year is a reasonable limit. This rate allows for an integration of new inhabitants into the local community without a disruption of the traditional rural style of life." (Šuška et al., 2013).

The examined suburban settlements are characterised by different developmental potentials; in spite of that, however, intensive construction activity is underway in all of them as new residential zones are being developed.

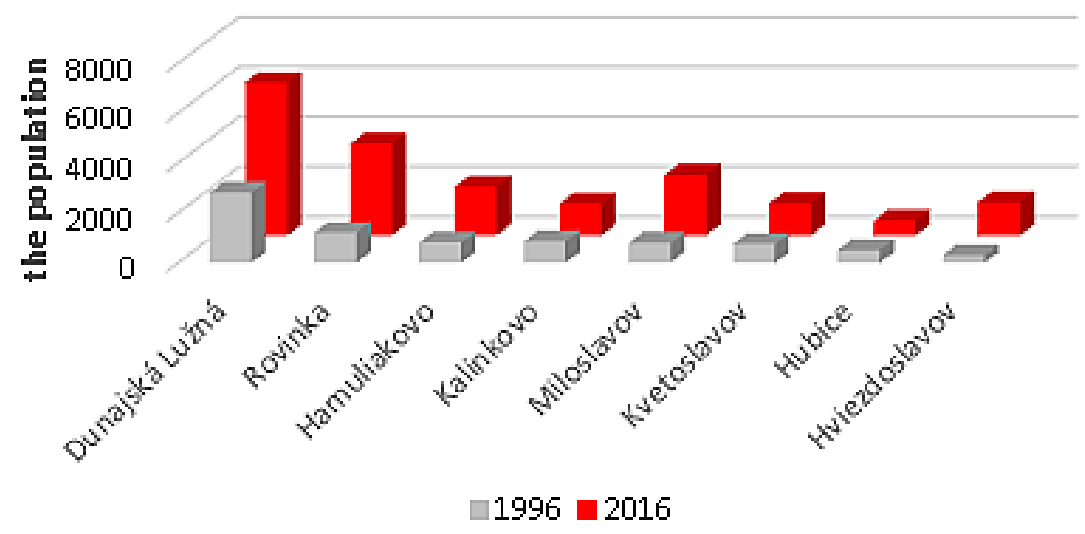

Fig 5. Increase in population of examined rural settlements on the Dunajská Streda development axis in $1996-2016$. Source: Statistical Office of the Slovak Republic, DataCUBE database

When selecting sample rural settlements, the following criteria were considered (Figure 6):

- $\quad$ hierarchy, location and size of the settlement within residential structure (connection to principal regional road and railway transport corridor Bratislava - Dunajska Streda)

- distance to central residential areas - downtown Bratislava (up to $25 \mathrm{~km}$ ), traffic availability and availability with respect to the time of travel

- dynamics of settlement growth - intensive construction activity in new residential zones and enormous increase in population from 1996 to 2016 in comparison to the original state (from $118 \%$ to Hubice up to $448 \%$ in Hviezdoslavov) - Fig. 5

- development policy characterised by significant pressure of developers on new residential zones resulting in extensions to the original local plan and changes in the overall character of the rural settlement and the surrounding countryside. 


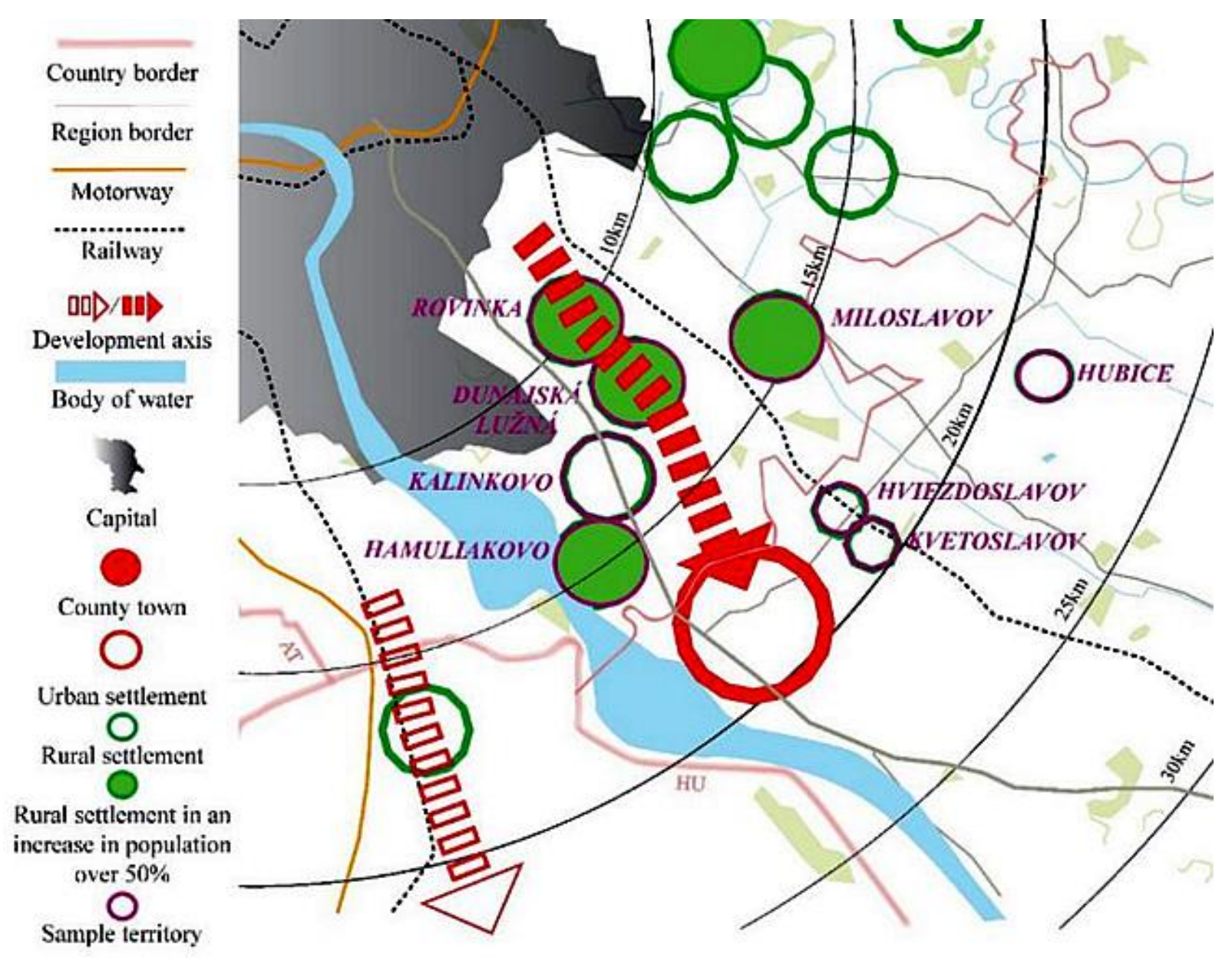

Fig 6. Chart showing the location of the sample territory within the residential structure. Source: Original research, 2018

Concerning the potential of individual locations, Rovinka and Dunajská Lužná have the best position in the settlement structure, as they lie closest to the centre of Bratislava on a principal regional road Bratislava-Dunajská Streda-Komárno. This advantage, however, is offset by excessive traffic that accumulates in these settlements as transit is directed via their built-up areas. The Hviezdoslavov, Miloslavov, and Kvetoslavov settlements have an advantageous location close to the railway line integrated in Bratislava's public transport system. The other settlements (Kalinkovo, Hamuliakovo, and Hubice) are located away from major transport corridors and are predominantly dependent on passenger vehicles.

A settlement's location has a significant impact on the structure of the public amenities. Amenities with regional significance accumulate along main transport routes, while settlements located in secluded areas in general only have necessary basic amenities.

\subsection{Terminology}

In rural structures in the vicinity of the Bratislava agglomeration (as well as close to other cities), urban and rural features blend. The countryside has a long time ago lost its traditional role as a place of production; importantly, this is connected to continuing acquisitions of fertile agricultural land and the associated weakening of the countryside's food independence and self-sufficiency. For the needs of this research, contemporary suburban rural settlements can be defined as "urban margins; satellites of the city in the sense of harmonising the relationship between the relatively complex nucleus and its orbit." (Jehlík, 2016, p.15).

In the present paper, public amenities mean "a wide range of facilities and functional areas designed to meet most diverse requirements of citizens of all ages." (AŽ Projekt, s.r.o., 2010) 
Public facilities in suburban settlements were examined for the following selected aspects::

- Location

- Accessibility

- Functional typology

- Relation between public amenities and public spaces

Territorial organisation of public amenities in a rural settlement is evaluated on the basis of its location, as delineated in existing local plans:

- In the centre of an urban structure: central part of a built-up area

- In the periphery of a built-up area within the urban structure: area outside the centre of the built-up area

- $\quad$ Outside the municipality's built-up area: the area of proposed and realised development plans outside the settlement's built-up area.

From the perspective of significance, public amenities are divided into basic and advanced. This division is closely related to a settlement's size and population density as well as the quantity and use of amenities. Basic public amenities cover the functions of providing buildings and facilities of local importance, especially for those who are present daily, i.e. living in the settlement. Concerning basic facilities, short walking distance and availability are emphasised. A 10-minute walking distance - corresponding to a straight line distance of $500 \mathrm{~m}$ - to an amenity is considered the maximum permissible threshold.

The functional variety of public amenities presently depends on many indicators, the most important being importance, administrative integration, priority function and location of the settlement in question within the urban structure, its distance from the central residential area and links to other settlements, size in terms of demographic indicators (e.g. population density and concentration), time of travel to individual facilities, and catchment area of public amenities.

As established in the methodological guide "Minimum Standards of Public Amenities in a Municipality", public amenities are classified into the following types on the basis of their function: education, sports facilities, health care, social services, cultural facilities, tourism, services, financial services, and public catering.

For the purposes of the present study, the functional typology of public amenities was partially modified as follows (Table 3): administration, cultural and ecclesiastical facilities, schools, medical facilities, retail amenities - groceries, other retail amenities, public catering, services for the population, other facilities, indoor and outdoor sports facilities - playgrounds.

Public amenities are undoubtedly also associated with public spaces. Since there is no clear legal definition of public space in Slovak legislation, it is necessary to define its characteristics. In this research, we consider "every open space ... under the sky" (J. Komrska, 2010, M. Jakušová 2010) a public space; it is defined by existing and planned boundaries of a municipality's built-up area and "accessible to the public; it is somehow attractive for both the locals and the visitors. A space is publicly accessible if it is free of charge always or for a longer part of the day. It is considered publicly accessible even if it is fenced and the caretaker closes it due to operational reasons for necessary maintenance or at night time for security reasons" (J. Komrska, 2010, M. Jakušová 2010).

\subsection{Research}

In the past, a traditional settlement was characterised by the square and the public amenities (church, tavern, shop, market, ...) situated around it, which formed and shaped the typical image and atmosphere of village public spaces, promoted social relations and supported cohesion within the population. It can be said that today, public amenities are very much involved in the revitalisation of public spaces and settlement identity. Similarly, according to the social ecologist Bohuslav Blažek, rather than detached houses straight out of catalogues, public spaces 
supporting specific aspects of social life are the primary topic in contemporary suburban countryside (Blažek, 2004). However, this function is being undermined by new constructions which give rise to new local centers on peripheries of towns and villages. An urban structure developed over a long time with a stable, clear environment and identity is gradually being disturbed. Given the aforementioned situation regarding areas intended for meeting, it is hardly surprising that "residents of new residential locations are considered socially isolated individuals who use the suburbs as a dormitory and are not interested in a deeper integration into the local community or in a participation in social life in the municipality." (Šveda, 2016, p.140)

The centre's functional diversity determines the number of visitors and the attractiveness of the municipality. Public amenities provide an indicator of quality and vitality of public spaces. A sparser distribution of public amenities in the peripheral parts, as well as a low degree of multifunctionality of the centre, reduces the importance of the settlement in the residential structure.

The examined percentage of public amenities in public spaces of the sample territories are, with regard to all selected urbanist indicators, taken into account because of their location in the settlement, the dimensions of the built-up area and the currently realised development plans, or the parcelled out plots that are ready for construction, based on an applicable local plan.

\subsubsection{Public amenities accessibility}

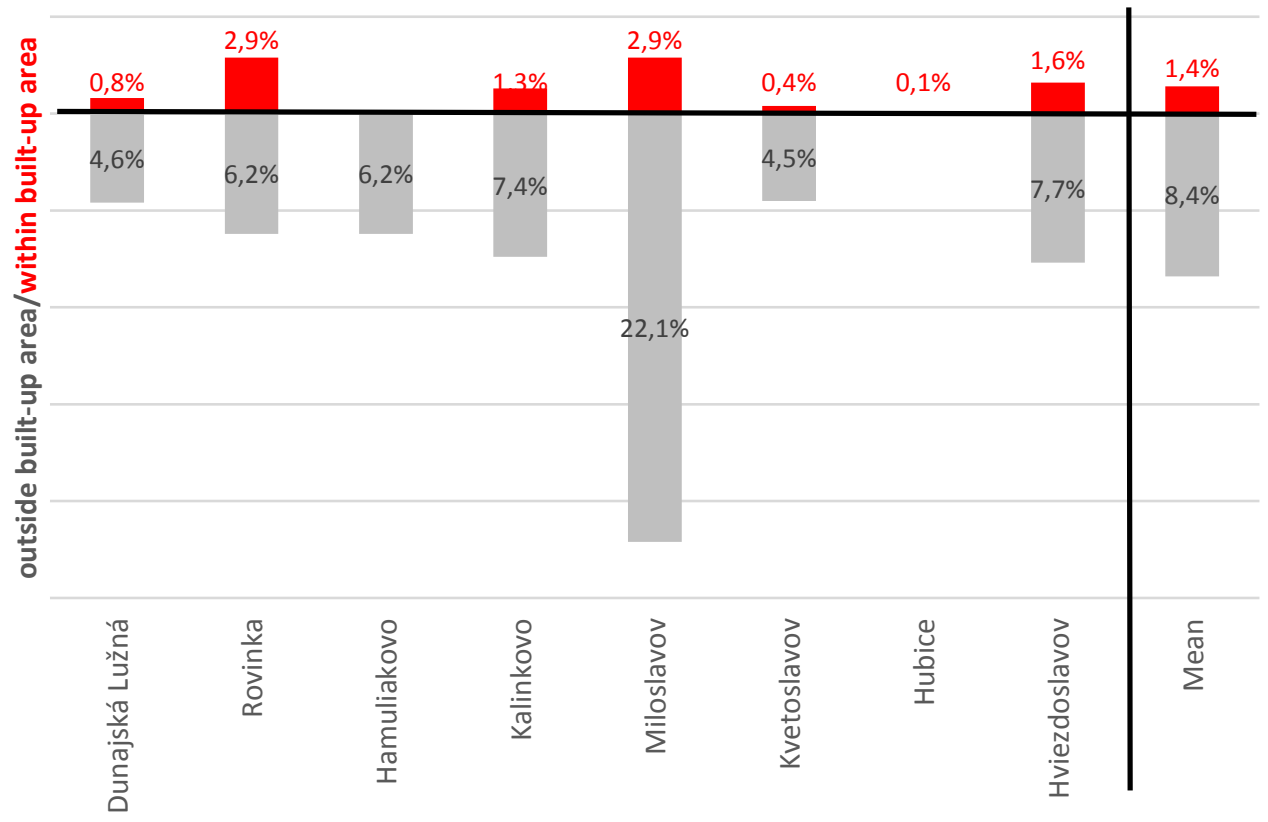

Fig 7. Residential areas within and outside the built-up area with a distance to basic public amenities of over $500 \mathrm{~m}$. Source: Original research, 2018

According to a technical report entitled "Towards a Local Sustainability Profile: European Common Indicators" that was approved by the European Commission, accessibility by foot is one of the five basic indicators of sustainable development (Šilhánková, 2003).

From the perspective of selected coverage by public amenities in the residential area (distance up to $500 \mathrm{~m}$ ) in sample rural settlements, the following findings were made (Fig. 7)

- In built-up areas, basic public amenities do not cover a space of $\mathbf{1 1 . 5}$ ha on average falling to a single settlement; this means $9.99 \%$ out of all current built-up areas.

- Outside the built-up areas, basic public amenities are lacking on average in the area of 64.25 ha belonging to a single settlement, representing $58.7 \%$ out of all completed development plans. In realised development plans outside the built-up areas in the sample territory, basic public amenities are absent in a residential area covering 513.55 ha 
(415.72 ha in settlements on the main railway and road). Kohout et. al. (2016) stated that these residential zones are dominated by private spaces and areas dedicated to traffic services.

Based on the above, it is observed that $8.4 \%$ of new residential areas are not covered by the basic public amenities at a pedestrian accessibility of up to $500 \mathrm{~m}$. The present study has reached a similar conclusion as Maštalka and Robová, who point out that in suburban territories, "the walking distance to individual services in new areas is much higher." (Maštálka, Robová, 2016:130). However, this finding is also connected to the development of the examined sample territories. In settlements with good transport availability, the proposed development represents an average increase of $327 \%$ in the current boundary of the built-up area, while in secluded settlements it is only $38 \%$.

When assessing sample territories in terms of basic amenities location, the trend was confirmed (Table 1):

- Sparser distribution in small settlements (Kalinkovo, Hubice, Hviezdoslavov, Miloslavov):

- Retail facilities loosely distributed in built-up area

- Sports areas and facilities concentrated on the margins, frequently outside the municipality's built-up area (Table 1)

- Greater concentration in settlements on principal regional transport corridors (Rovinka, Dunajská Lužná); this is related to the facilities' location potential and economic benefits for businesses.

\subsubsection{Public amenities locations}

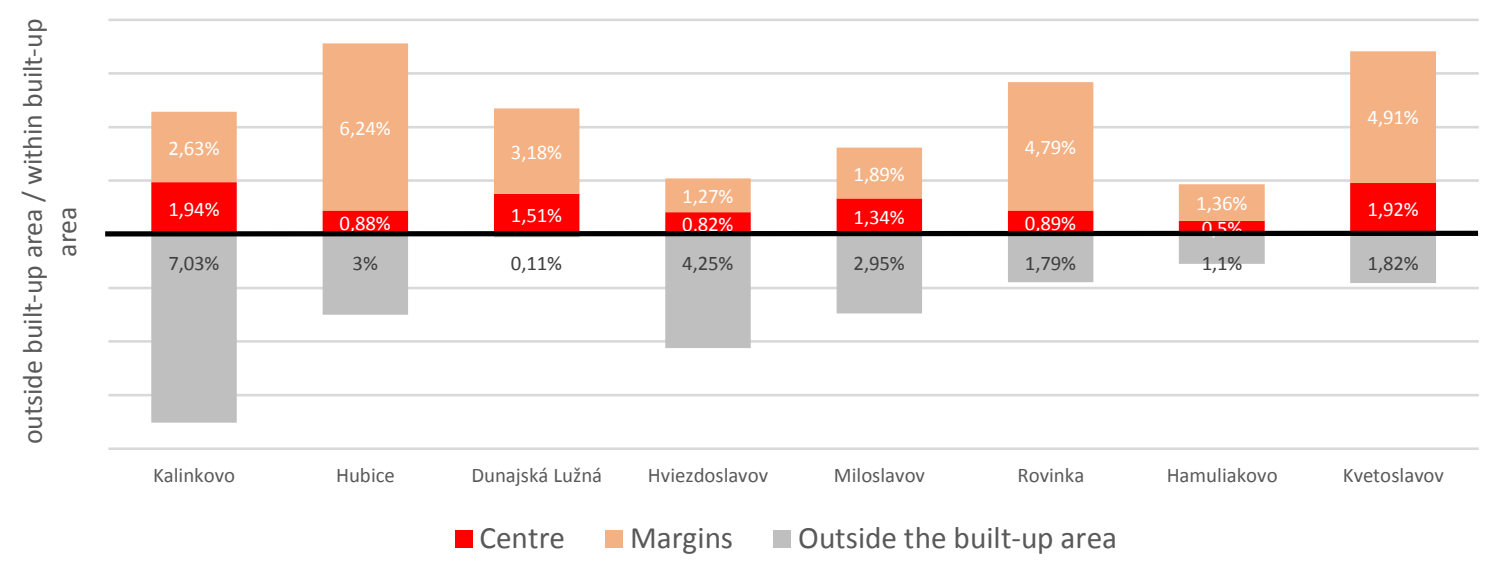

Fig 8. Classification of public amenities in the sample territory according to location. Source: Original research, 2018

In rural settlements, the ratio of the area covered by public amenities to the total surface area of the built-up structure delimited by the boundary of the built-up area (intravilan) and to the total area of completed development plans outside the boundary of the built-up area was monitored. By means of comparison, the following findings were made:

- On average, public amenities cover the area of $8.45 \%$ (Figure 8 ), out of which:

- In municipalities' built-up area, centre and margins it is $6.97 \%$ - values range from $2.96 \%$ in the Hamuliakovo municipality to $9.91 \%$ in Kalinkovo municipality

- Outside the built-up area, it is $1.48 \%$ - values range from $0.11 \%$ in the Dunajská Lužná municipality to $7.03 \%$ in the Kalinkovo municipality.

Built-up area boundaries were established in local plans for all municipalities in 1966 and 1990; in the following years, they have been subject to the settlement's requirements. 


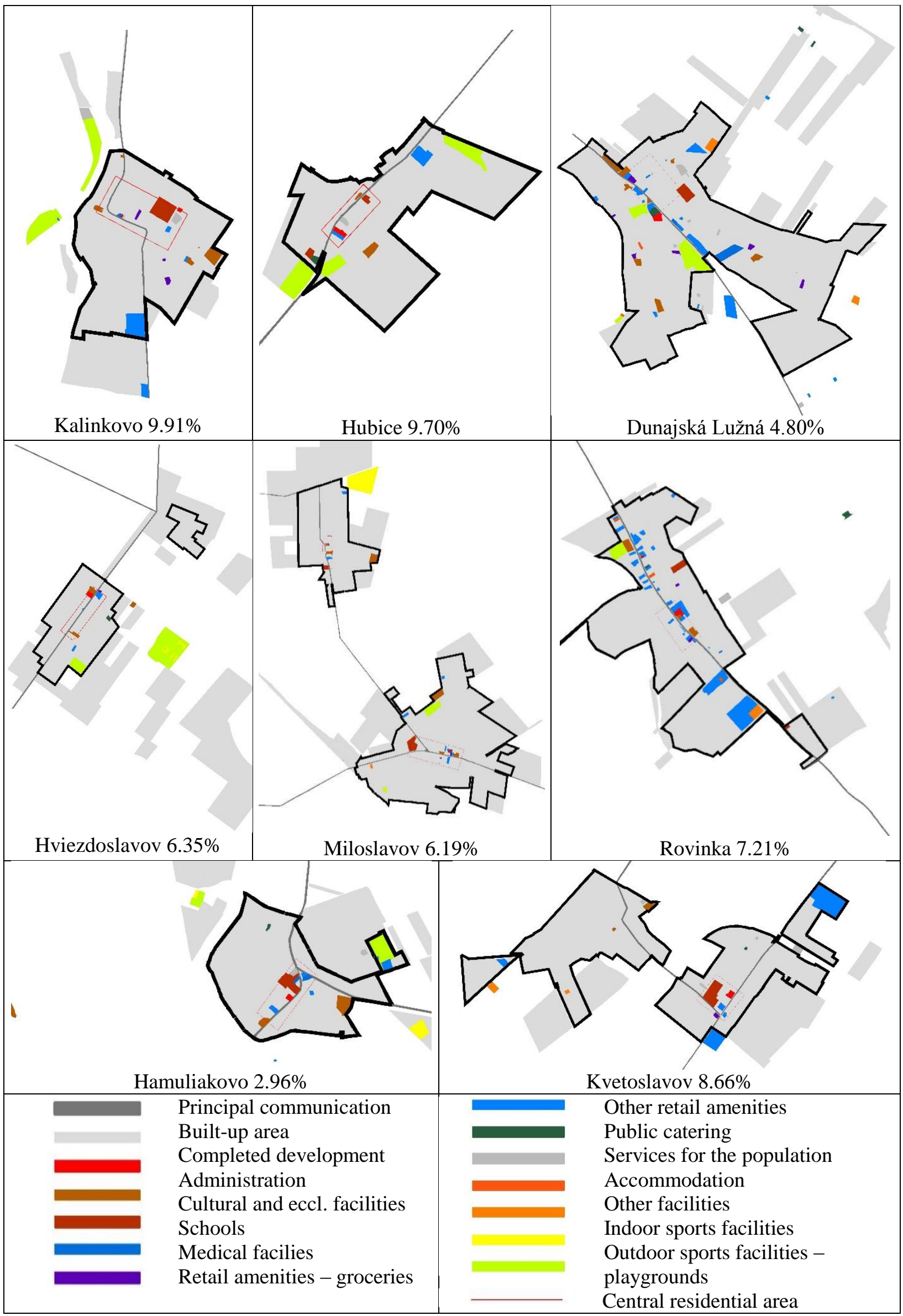




\subsubsection{Functional classification of public amenities}

In legislative materials, the specifics of functional classification of public amenities have received increased attention. In the methodology guide of the Ministry of Transport and Construction of the Slovak Republic called "Minimum Standards of Public Amenities in a Municipality" (updated in 2009), an emphasis is placed on general principles, such as the need for public amenities concentration, the hierarchy of amenities in the centres, their relation to recreational and other functions, alongside the obligatory and recommended parameters of public amenities in municipalities. Therefore, the construction and technical condition of individual buildings of public amenities cannot be omitted. "Urban architecture needs to engage with the environment and provide any visitor with entertainment, functions, opportunities, distractions, multiple perceptions or living spaces." (Štefancová, 2013)

In the field survey, it was discovered that some of the original facilities underwent reconstruction for which EU funds were used (e.g. municipal authorities, primary schools - window replacements...). Retail facilities and services that are predominantly privately owned are in a significantly worse technical and structural condition.
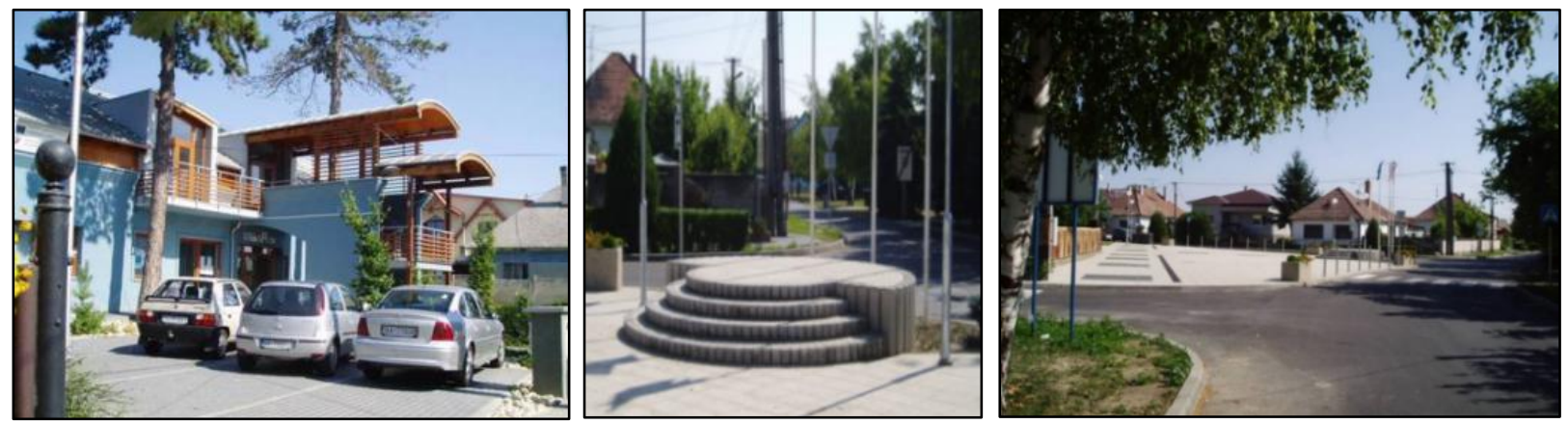

Fig 9, 10, 11. Hamuliakovo - the seat of municipal authority (reconstruction funded by the EU) and the community centre with a public space. Credit: A. Sopirová, 2014
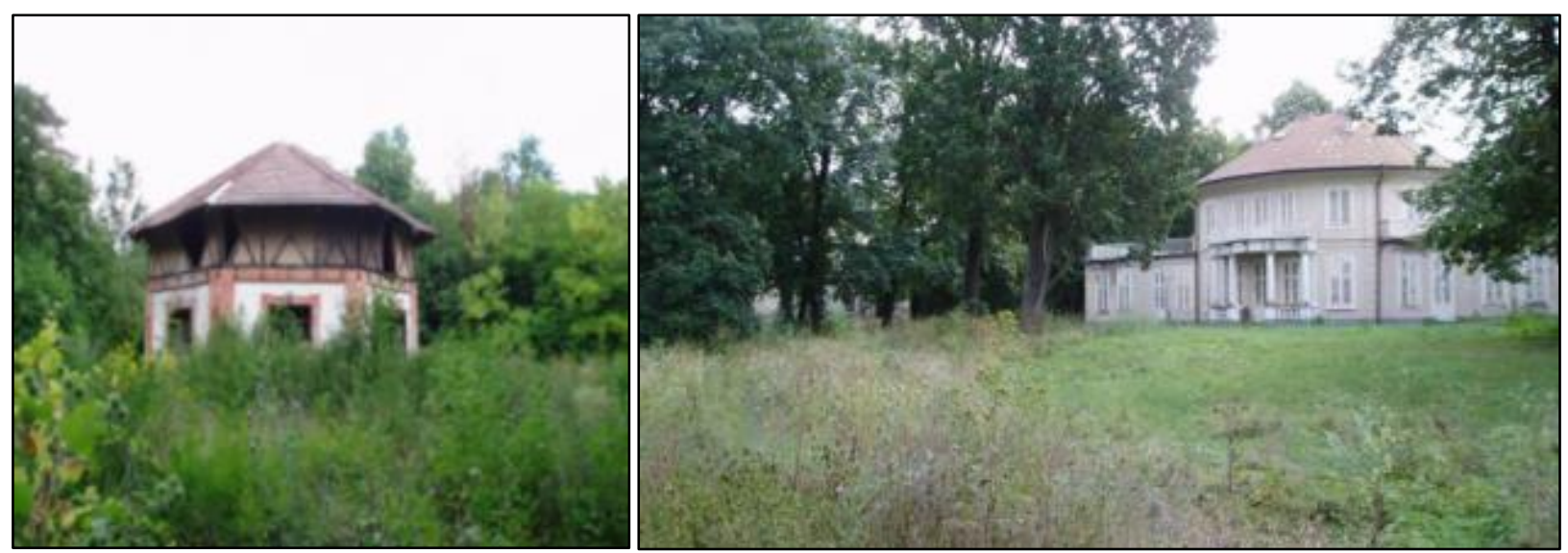

Fig 12, 13. Hubice - dilapidated manor and original stables surrounded by a protected park. Credit: A. Sopirová, 2008 
Tab 2. Functional composition of public amenities within and outside built-up areas in the sample territory. Source: Original research, 2018

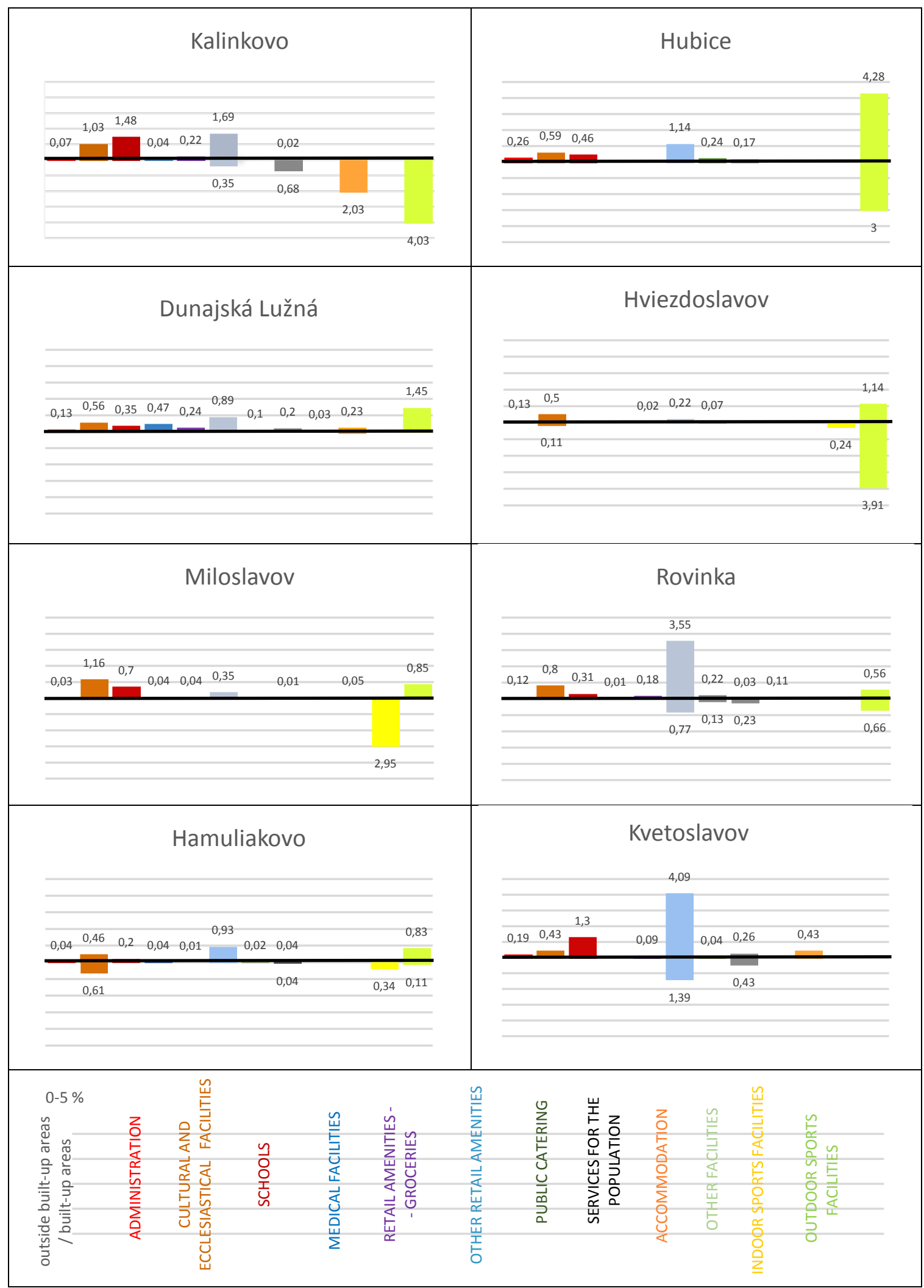


Tab 3. Percentages of public amenities in area covered. Source: Original research

\begin{tabular}{|l|c|c|c|c|}
\hline \multirow{2}{*}{ Type of public amenity } & \multicolumn{2}{|l|}{$\begin{array}{l}\text { Overall share (\%) of public } \\
\text { amenities (within and outside } \\
\text { built-up area boundaries) in the } \\
\text { total built-up area }\end{array}$} & $\begin{array}{l}\text { Average share } \\
\text { (\%) of public } \\
\text { amenities in } \\
\text { built-up area } \\
\text { only out of the } \\
\text { total built-up } \\
\text { area }\end{array}$ \\
\hline Administration & 0.04 & 0.26 & 0.12 & 0.12 \\
\hline $\begin{array}{l}\text { Cultural and ecclesiastical } \\
\text { facilities }\end{array}$ & 0.43 & 1.07 & 0.78 & 0.75 \\
\hline Schools & & & Highest & Average \\
\hline Medical facilities & 0.00 & 1.48 & 0.60 & 0.60 \\
\hline Retail amenities - groceries & 0.00 & 0.47 & 0.15 & 0.15 \\
\hline Other retail amenities & 0.00 & 0.24 & 0.10 & 0.10 \\
\hline Public catering & 0.22 & 5.48 & 2.56 & 1.60 \\
\hline Services for the population & 0.02 & 0.24 & 0.08 & 0.08 \\
\hline Accommodation & 0.00 & 0.07 & 0.26 & 0.09 \\
\hline Other facilities & 0.00 & 0.11 & 0.02 & 0.02 \\
\hline Indoor sports facilities & 0.00 & 2.03 & 0.34 & 0.09 \\
\hline Outdoor sports facilities & 0.00 & 0.00 & 2.95 & 0.44 \\
\hline
\end{tabular}

By way of comparing areas of functional types of public amenities (both in the boundaries of the built-up area in the municipality and outside the built-up area) to the total area delimited by the boundaries of the built-up area in the examined settlements, the following findings were made (Table 1,2,3):

- The greatest percentage of built-up area is covered by:

○ Outdoor sports facilities (playing fields) $-5.00 \%$

- Indoor sports facilities $-2.95 \%$

- Other retail amenities $-2.56 \%$

- The lowest percentage of built-up area is covered by:

○ Accommodation $(0.02 \%)$

- Public catering $(0.08 \%)$

- Retail amenities - groceries $(0.10 \%)$

- Medical facilities (0.15\%)

The survey revealed that in many settlements, there are no basic medical facilities, outpatient clinics (a general practitioner for children and adults), schools (the Hviezdoslavov municipality with 1,348 inhabitants in 2016). There are no social care facilities in the area covered in this research.

\subsubsection{Size of public amenities}

Public amenities also comprise lands, which may be classified as public spaces depending on the function of prominent buildings.

The ratio of the area covered by buildings of public amenities and adjoining lands to the total builtup area and completed development plans in a municipality shows that (Figure 14):

- Secluded settlements have on average the greatest share of plots, $9.08 \%$; correspondingly, they also have the smallest share of buildings, $0.41 \%$

- Setllements in attractive environments on average comprise $6.43 \%$ of land and $0.63 \%$ of buildings

- Settlement near prominent traffic corridors have on average the smallest area covered by plots, 5.56\%; correspondingly, they also have the greatest share of buildings, $1,04 \%$ 


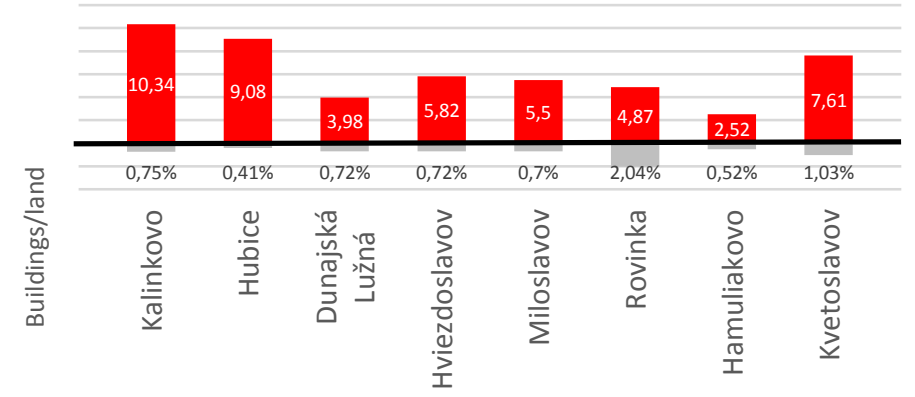

Fig 14. Representation of built-up and unoccupied land in public amenities in comparison to the total surface area of the built-up and undeveloped land. Source:Original research, 2018

These facts are related to land price which is dependent on the location potential of a settlement and the land itself, as well as on its access to transport and technical infrastructure.

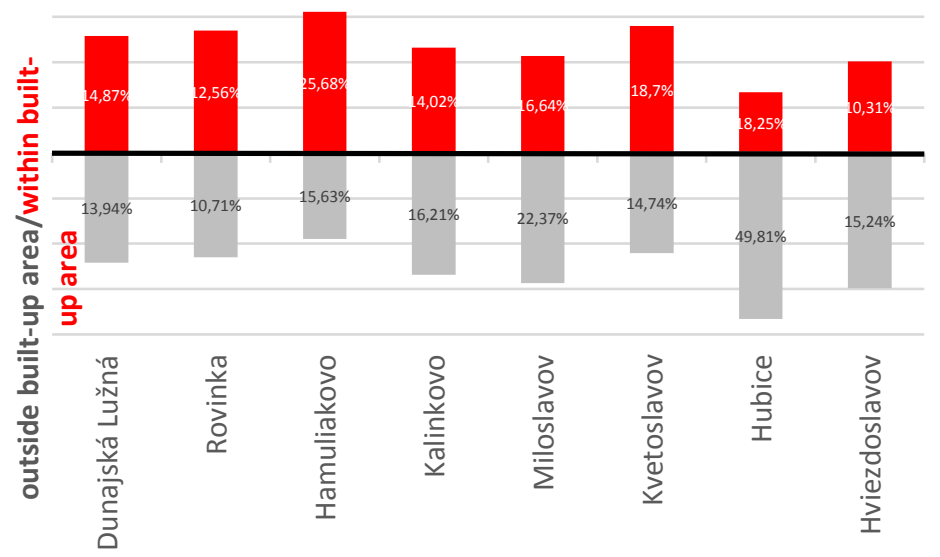

Fig 15. Comparison of percentage of public spaces within and outside the built-up area in examined settlements. Source: Original research, 2018

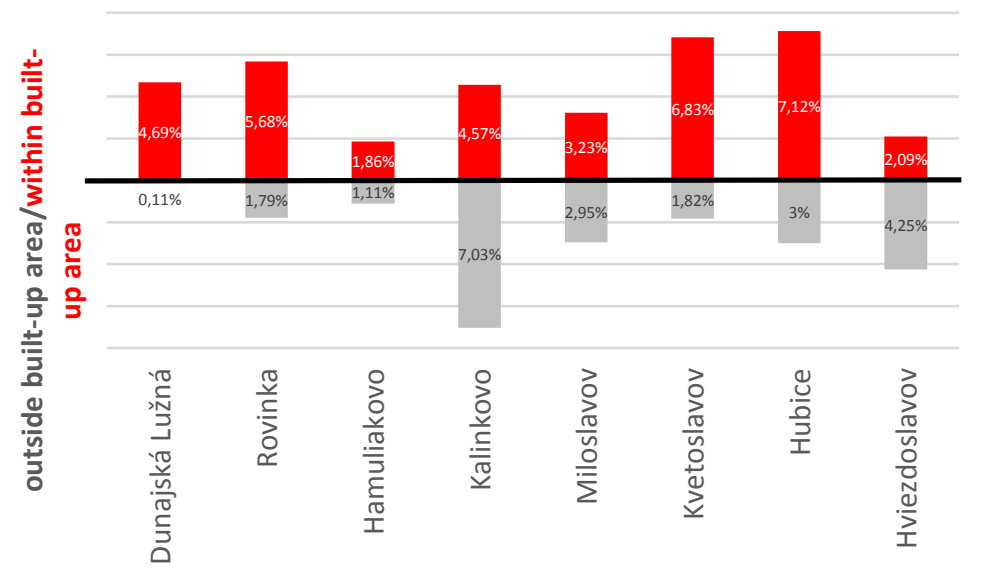

Fig 16. Comparison of percentage of public amenities within and outside the built-up area in examined settlements. Source: Original research, 2018 


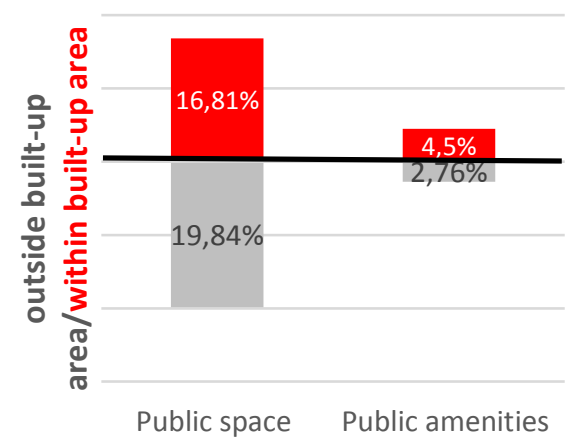

Fig 17. Comparison of percentage of public spaces and public amenities within and outside the built-up area in examined settlements. Source: Original research

The comparison between average size of public spaces and public amenities and total built-up area led to the following findings:

- Secluded settlements have the largest relative area of public spaces (68.06\%) and public amenities $(10,1 \%)$

- Settlements in an attractive environment and in the proximity of prominent traffic corridors have in comparison roughly twice smaller relative area of public spaces $(32.29 \%$ and $30.10 \%$, respectively) and public amenities (6.13\% and $6.69 \%)$

Similar average percentages of public spaces in both built-up and and unoccupied areas of sample settlements are not reflected in the average percentage of their public amenities.

The largest percentage of public spaces is in the municipality of Hubice (68.06\%), which is situated in a peripheral position within the studied settlement structure. Public areas in the municipality comprise a manor and a large park of 40 ha manifesting an original natural/landscape garden character, which is situated in the centre of the municipality. The building is in the present in private ownership, including the park that is currently disused, closed to the public and gradually dilapidating (Figures 15, 16, 17, 12, 13).

\subsubsection{Percentage of public amenities per capita}

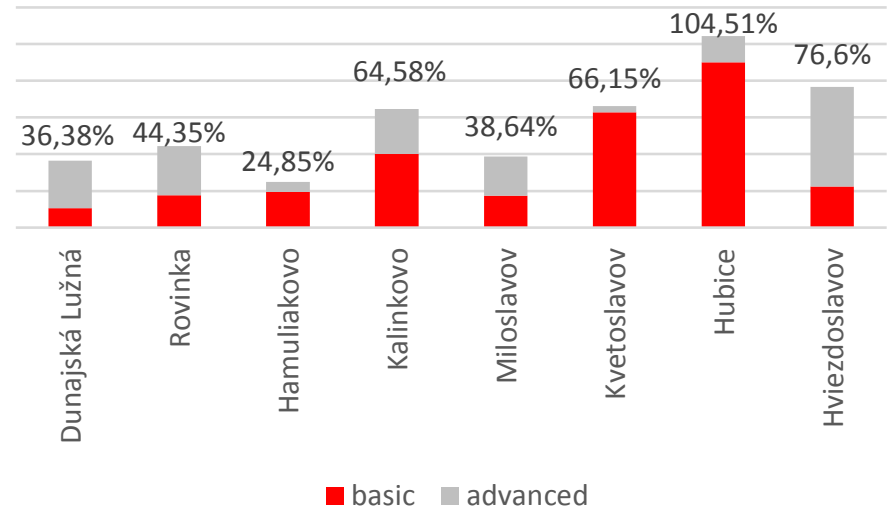

Fig 18. Division of public amenities according to function per inhabitant in individual settlements. Source: Original research, 2018 


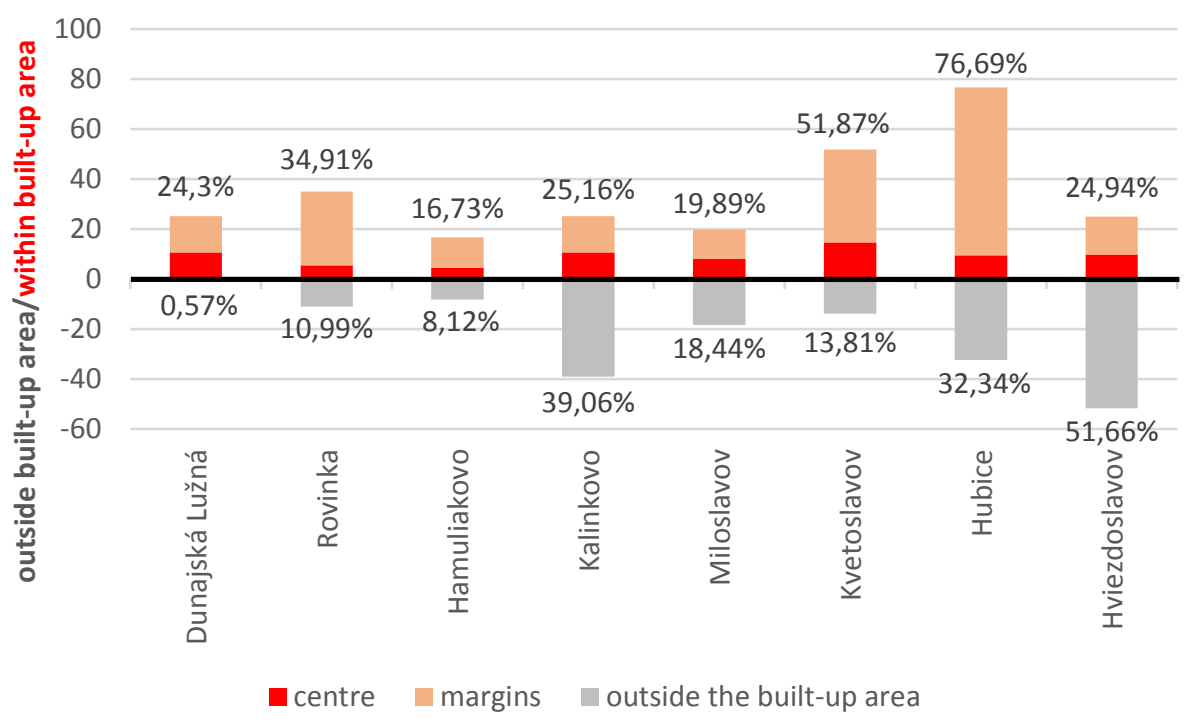

Fig 19. Division of public amenities according to location per inhabitant in individual settlements. Source: Original research, 2018

The average value of built-up area covered by public amenities per capita is $6.24 \mathrm{~m}^{2}$ in the examined rural settlements, ranging from $4.44 \mathrm{~m}^{2}$ in Hubice up to $12.52 \mathrm{~m}^{2}$ in Rovinka.

The average ratio of land taken up by public amenities per inhabitant is $48.99 \mathrm{~m}^{2}$ in the examined rural settlements, ranging from $21.12 \mathrm{~m}^{2}$ in Hamuliakovo up to $97.77 \mathrm{~m}^{2}$ in Hubice, while:

- The largest public space per capita $\left(104.51 \mathrm{~m}^{2}\right)$ is in secluded locations

- In settlements in the proximity of prominent traffic corridors, the ratio is twice lower: $52.42 \mathrm{~m}^{2}$ per capita

- The smallest public space per capita of $44.72 \mathrm{~m}^{2}$ is in attractive environments

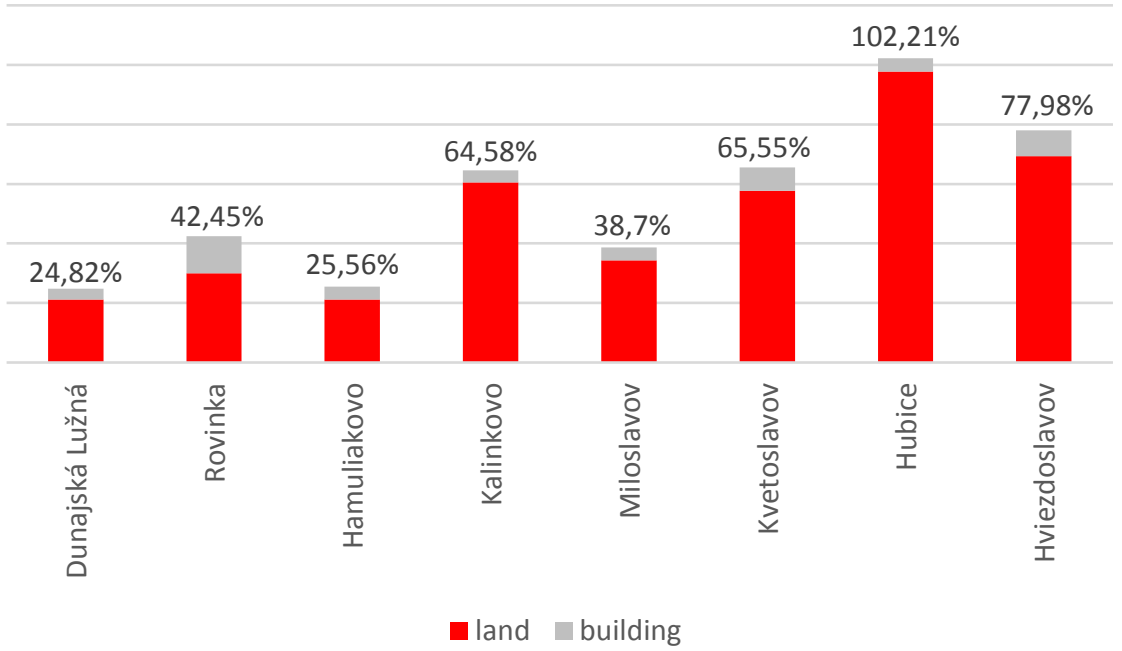

Fig 20. Public amenities coverage per inhabitant in individual settlements. Source: Original research, 2018 


\subsubsection{Comparison of research results and public amenities standards}

Currently, the "Minimum Standards of Public Amenities in a Municipality" gives recommendations regarding the basic conditions of typology, location and percentage representation of public amenities in rural settlements; public amenities are regarded as functional components of the whole. The document defines the basic requirements arising from Building Act 50/1976 Col. on local plans and building regulations, the decree of the Ministry of Environment of the Slovak Republic No. 55/2001 Col. on land-use planning and territorial planning documentation, and other related legislation effective in the Slovak Republic (AŽ Projekt s.r.o., 2010). The guide was prepared by the Ministry of Environment of the Slovak Republic, the update in 2010 was completed by the AZ Projekt studio.

A sample rural settlement has an average of 2338 inhabitants in an area of 158 ha, which according to the methodological guide falls into the size category 2 . Given the settlement size, it is possible to ascertain recommended facilities of a specific public amenities category or alternatively similar facilities complementing the requirements with units addressing a specific purpose in order to guarantee appropriate public amenities for the given location. Based on the guide's recommendation, there should be 14 seats in cultural facilities, 10 jobs in accommodation facilities, 8 schools, 6 service facilities and grocery retailers, 2 outpatient departments, a cemetery covering 0.7 ha and sports facilities on the area of 0.6 ha in the sample area. Besides the number of seats and jobs, benchmarks also include walking distance (500$1200 \mathrm{~m}$ ) and an average area of the plot ( 0.1 to $0.8 \mathrm{ha}$ ) depending on the type of public amenities.

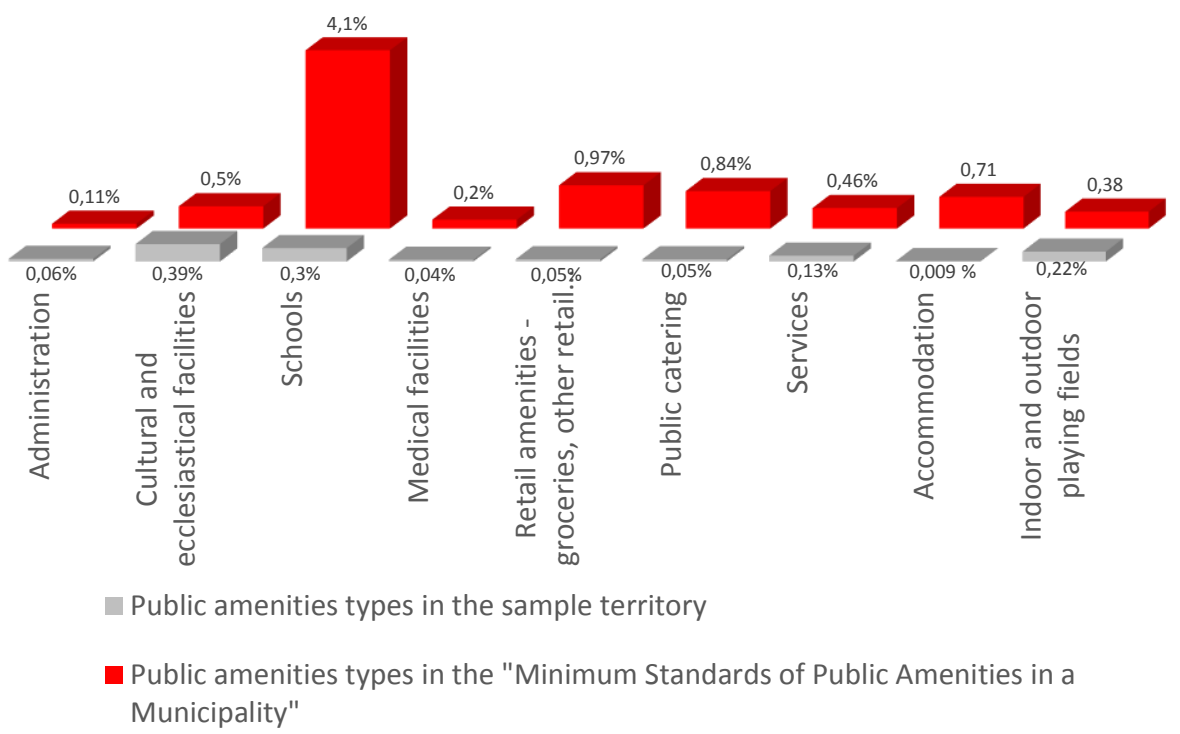

Fig 21. Comparison of percentage representation of public amenities types in the sample territory and according to the "Minimum Standards of Public Amenities in a Municipality". Source: Original research, 2018

A comparison of the public amenities percentage in an average settlement structure of the sample area to the recommendations of the "Minimum Standards of Public Amenities in a Municipality" revealed that social services facilities are completely absent, the number of schools is significantly lacking $-3.8 \%$ of the total area of the settlement, followed by retail amenities $-0.92 \%$ of the total area, and public catering $-0.79 \%$. The municipalities attempt to compensate the unsatisfactory situation in the education sector by division into smaller classrooms, various building extensions, building completions and container classrooms, but the demand continuously exceeds school capacities, as a result of which pupils are forced to travel to larger cities, or schools are forced to organise two-shift operation. In Šamorín, the town representing the catchment area of the sample territory, the situation is also alarming as the schools gradually and repeatedly take measures in the form of administrative reduction of the area covered by the local school. The absence of retails and catering is gradually compensated by the construction of smaller shopping centres mostly on the margins, which disrupts the original rural character of the settlement. However, the daily 
commute of inhabitants to the city continues, and not only because of work, but primarily because of educational, medical and cultural facilities.

The present research revealed a lack of all types of public amenities in the sample area, with the smallest difference compared to recommendations in case of sports facilities - indoor and outdoor playing fields $(0.16 \%)$, cultural and ecclesiastical facilities $(0.11 \%)$, and administration $(0.05 \%)$. Moreover, the observed percentual differences can only be considered approximate, due to the poor motivation of new residents to register for permanent residence in the examined settlements.

\subsubsection{Comparison of research findings to the character of public amenities in urban structure}

A research of public amenities as one of the indicators of quality of life was also undertaken in detail by Maštálka and Robová (Maštálka, Robová, 2016). They examined selected primarily rural villages or hamlets that had over time been absorbed by a growing city and had become a part of it. The study was focused on mapping public amenities and comparing their presence in housing estates and single-family housing zones.

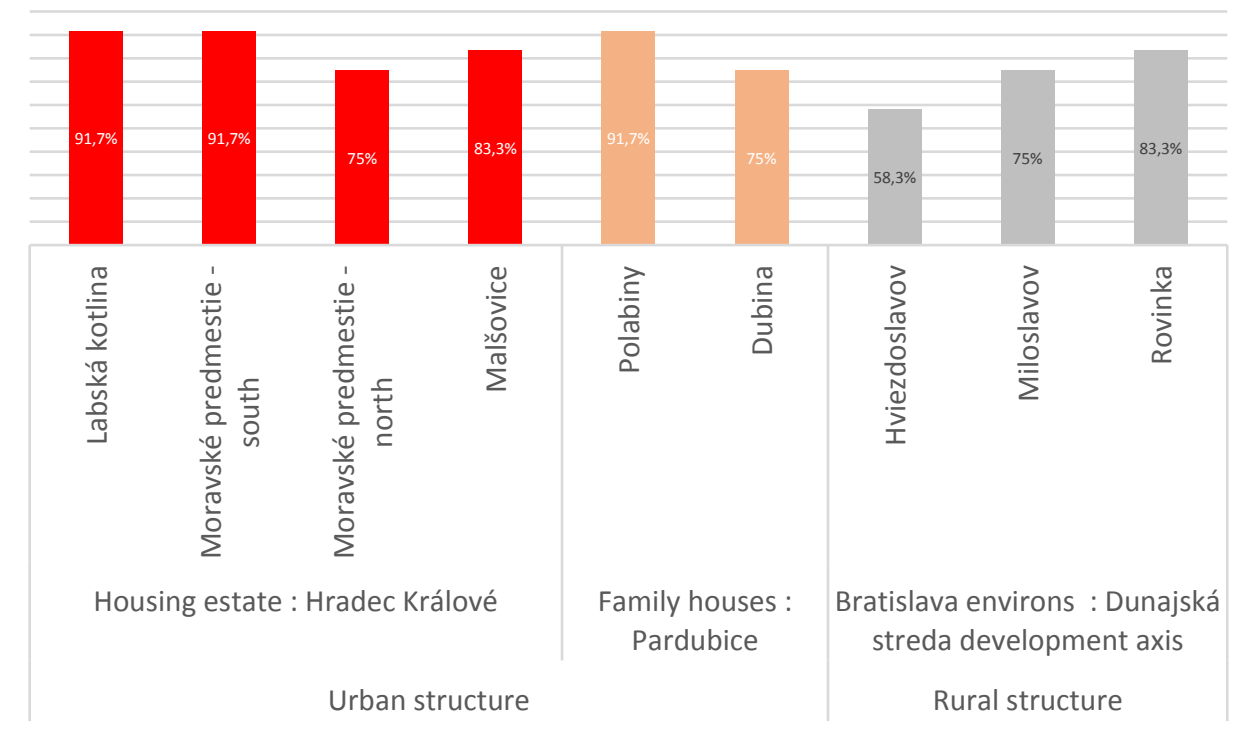

Fig 22. Types of public amenities in original settlement structure. Maštálka, Robová, 2016, original research, 2018

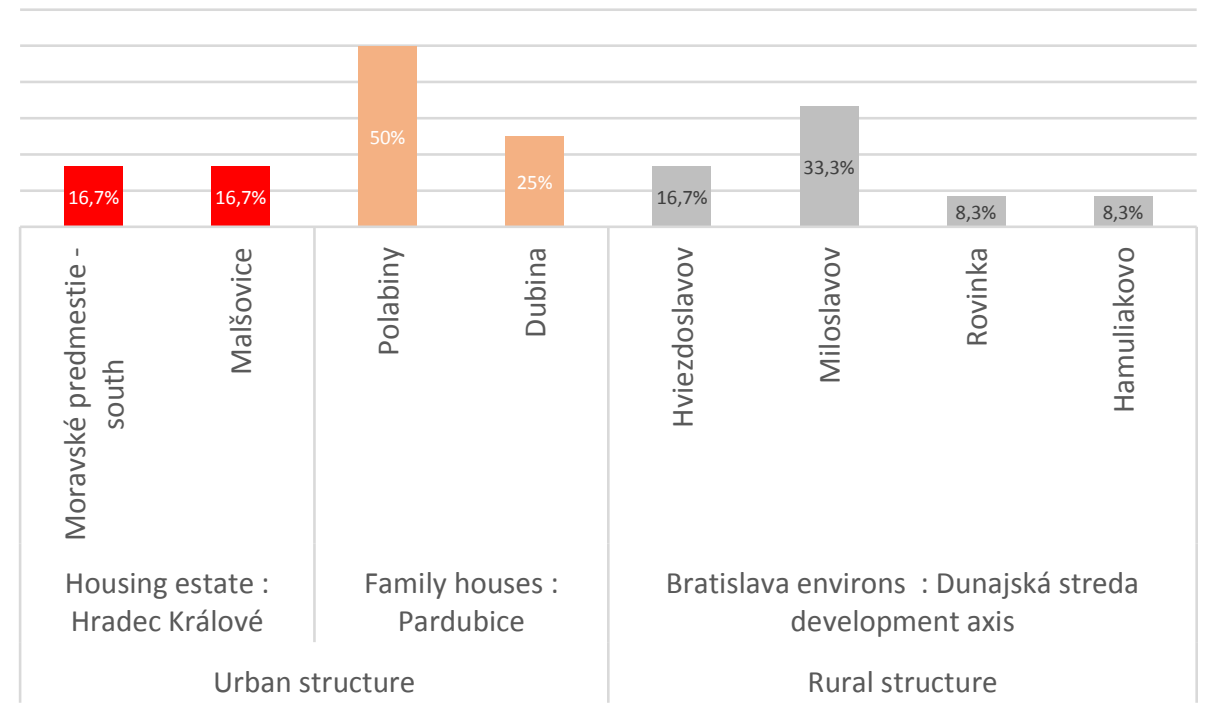

Fig 23. Types of public amenities in new settlement structure. Maštálka, Robová, 2016, original research, 2018 
The findings of this research concerning typological representation of public amenities were compared to values discovered in four rural settlements in the present sample area (Hviezdoslavov, Miloslavov, Rovinka and Hamuliakovo; percentual growth of $453.9 \%-244.7 \%$ of the population).

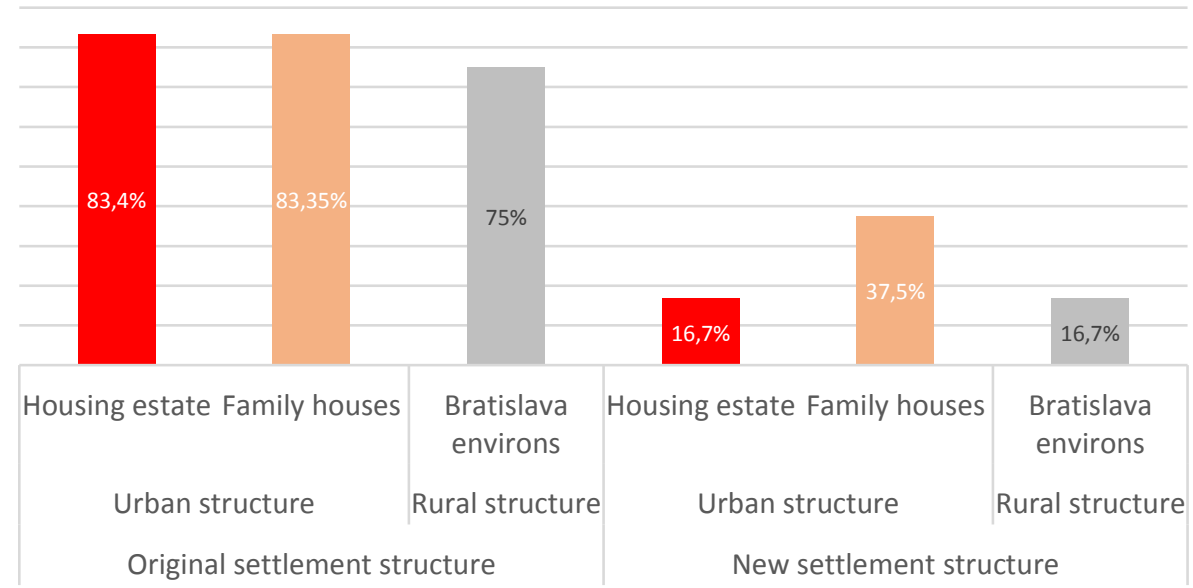

Fig 24. Summary comparison of a new urban structure in a city to a part of the sample rural area. Maštálka, Robová, 2016, original research, 2018

Figures 22, 23, 24 show the differences according to type in representation of public amenities in urban (housing estate and single-family housing zones) and rural structure with regard to their locations.

The comparison of research findings to the character of public facilities in urban structure produced the following conclusions:

a) Original settlement structure

- The greatest typological variety of public amenities occurs in urban structure: average in housing estate zone $-85.4 \%$, single-family housing zone $-83.4 \%$

- In rural structure, the share of public amenity types is on average only $9.4 \%$ lower: rural structure $-75 \%$ )

b) New settlement structure

- The greatest typological variety of public amenities occurs in urban structure $-27.1 \%$; surprisingly, however, single-family housing zone has a higher share $-37.5 \%$, followed by housing estate zone $-16.7 \%$

- In rural structure, percentage share of public amenity types is on average identical to new housing estate areas $-16.7 \%$

- In new rural structure, percentage share of public amenity types is on average $58.3 \%$ lower

\section{Conclusion and discussion}

\subsection{Summary}

\subsubsection{Hypothesis 1}

Based on an examination of commuting distance, location, area of public amenities and allocation of public amenities per capita in the sample territory, the following conclusions were reached:

- Public amenities locations clearly stem from the location of the settlement in the settlement structure, its dominant function and transport accessibility to the central residential area 
- $13.36 \%$ of the built-up areas in sample municipalities and $89.35 \%$ of new residential zones lack basic public amenities available to pedestrians, i.e. within a distance of $500 \mathrm{~m}$ (Figure 7)

- It was confirmed there is a direct dependence between the location of advanced public amenities and links of a rural settlement to a central residential area, the most important criteria being distance and transport accessibility (Figure 8)

- There is a disproportion in percentual representation of all types of public facilities; in the built-up area it is $6.97 \%$, while outside the built-up area it is only $1.48 \%$ (Figure 14)

- The following findings were made regarding secluded settlements (Hubice):

- The largest plots $-9.08 \%$, which is connected to the smallest built-up area $-0.41 \%$ (Figure 14)

- The largest share of public spaces $-68.06 \%$ (Figure 15)

- The largest area of public space per capita - 104.51\% (Figure 18)

○ The greatest share of public amenities $-10.1 \%$ (Figure 19)

- The following findings were made regarding settlements in attractive environment (Hamuliakovo, Kalinkovo):

- Average plot area $-6.43 \%$, which is connected to average built-up area per building $-0.63 \%$ (Figure 8 )

- Average share of public spaces - 32.29\% (Figure 18)

- The smallest area of public space per capita $-44.72 \%$ (Figure 18)

○ The smallest share of public amenities $-6.13 \%$ (Figure 19)

- The following findings were made regarding settlements in the proximity of prominent traffic corridors (Rovinka, Dunajská Lužná, Kvetoslavov, Miloslavov, Hviezdoslavov):

○ The smallest plot area $-5.56 \%$, which is connected to the largest built-up area per building, 1.04\% (Figure 8)

- The smallest share of public spaces $-30.1 \%$ (Figure 18)

- Twice smaller area of public space per capita than in secluded settlements $52.42 \%$ (Figure 18)

- Lower share of public amenities $-6.63 \%$ (Figure 19)

The present research has revealed that newly built areas in suburban rural settlements in the Bratislava environs "freeload off" of existing public amenities situated predominantly in the settlement's original structure alongside the main transport corridors. At the same time, previous studies (Sopirová, 2017) showed that residential areas located at peripheral locations of a settlement, which lack in public amenities, have significantly higher population densities than the settlement as a whole (Sopirova et al., 2017).

\subsubsection{Hypothesis 2}

The comparison of functional classes of public amenities in the sample territory with the applicable recommendations in the "Minimum Standards of Public Amenities in a Municipality" guide (Figure 8) :

- Insufficient area of public amenities $-7.02 \%$ of public amenities out of the recommended $8.3 \%$ are absent

- Insufficiency in all types of public amenities

- Complete absence of social services

- Alarming insufficiency of schools $-3.8 \%$ out of the recommended $4.1 \%$ 
$\circ$ The smallest insufficiency in sports facilities $-0.22 \%$ out of the recommended $0.38 \%$.

In the sample territory, the average area of public amenities per capita is $57.00 \mathrm{~m}^{2}$ (sum of the plot area and the built-up area associated with a building); it ranges from $24.84 \mathrm{~m}^{2}$ per capita in Hamuliakovo up to $104.51 \mathrm{~m}^{2}$ per capita in Hubice (Figure 18).

This research found that public amenities in suburban rural settlements in the Bratislava environs are insufficient in terms of capacity and type.

In her research into polyfunctionality of urban peripheries, the urbanist Melcerová states that for suburban single-family housing zones, non-residential functions need to be represented by at least $10-15 \%$ for the reasons of operational efficiency as well as mobility that would be efficient in terms of time and energy (walking or cycling). "It would be ideal to promote a functional mix of approximately $70 \%$ share of housing and $30 \%$ share of complementary functions, especially public amenities and services." (Melcerová, 2012). In the present sample area, public amenities comprise on average $6.97 \%$, failing to meet even the aforementioned minimal representation.

\subsection{Analysis of results}

On the basis of our findings, we can conclude that the results obtained from eight model rural settlements confirmed our hypothesis, fulfilling the primary research goal.

A research with the aim of gaining and extending the knowledge of the current state of existing and new structures in suburban rural settlements with a specific focus on public amenities can provide groundwork and recommendations for the regulation of new constructions in contemporary urban planning. Thus, it can also support values that guarantee a higher quality of life in urban, social, economic and environmental aspects. Public amenities play an integral part in animating social public spaces, and thus in the creation and activation of social contacts in a rural community. At the same time, its unique functional and spatial variability complements the composition, internal visual aspect, identity, atmosphere and genius loci of the picturesque countryside. Recommendations for minimum quantitative indicators related to public amenities in rural settlements in the suburban space of Bratislava are considered beneficial for contemporary urbanist, architectural and urban planning practices. It is anticipated they will be employed in interventions or proposals of new concepts of territorial development.

Given the current dynamic development of the area following the principles of a "free market economy", it is necessary to abide strictly by the regulations based on the local plans in effect. It is recommended to provide benefits, e.g. tax concessions, for economically unprofitable investments via legislation.

\subsection{Connection to other research}

The paper "Public Amenities in Rural Suburban Settlements in the Environs of Bratislava" is a part of an ongoing research of public spaces in the countryside. The purpose of researching the currently prominent topic of public spaces is, from an urbanist point of view, to provide a depiction of the issue that would be as comprehensive as possible and to propose possible remedies for the current state of new residential areas in the form of recommendations and regulations.

The aforementioned research was preceded by a quantitative evaluation of public spaces: their classification, ascertaining their locations, and a comparison of indicators within and outside the built-up area in selected settlements.

The discovered connections and observed urbanist parameters will be compared to formerly rural, peripheral parts of Bratislava, such as Záhorská Bystrica, Jarovce, Rusovce and Čunovo (because of an "urbanisation" of the countryside). In this context, comparisons can also be made with rural communities beyond the borders at the Vienna, Parndorf and Mošon development axes.

The quantitative analysis is followed by a qualitative assessment of principal public spaces. "Therefore, we consider it necessary, within the methodological framework of the public spaces 
assessment, to monitor public spaces in a comprehensive way - that is to monitor all relevant phenomena: material, functional, as well as social, cultural ..." (Vitková, 2015, p.24).

There emerged a collaboration with an aim of improving the quality of life in new development areas and regulating development projects, which resulted in a currently ongoing exhibition of 24 student proposals. These deal with the original central structure of the settlement, the street Ulice Československých tankistov, and the new development area Ivance in its immediate proximity. The questionnaire survey among the inhabitants of Záhorská Bystrica should shed light on their opinions, attitudes and beliefs regarding the most pressing and discussed topics of their public lifes. The resulting evaluation chart will show the differences between the attitude of the population, the current state, and its recommended solution.

Academic references

[1] Bailoni, M., Edelbutte, S. \& Tchékémian, A. (2012). Agricultural landscapes, heritage and identity on peri-urban areas in Western Europe. European Countryside 4(2), 174-161. DOI: 10.2478/v10091-012-0020-9.

[2] Baše, M. (2006). Sídla a stavby na venkově. Praha: Česká technika - nakladatelství ČVUT.

[3] Blažek, B. (2004). Venkovy: anamnéza, diagnóza, terapie. Vol. 1. Brno: Era.

[4] Gajdoš, P. (2002). Člověk, spoločnost', prostredie. Bratislava: Sociologický ústav SAV.

[5] Gajdoš, P. (2009). Globalizačné súvislosti urbánneho vývoja a jeho sociálnopriestorové špecifiká. Sociológia 41(4), 204-328.

[6] Görner, K. (2017). Slovak housing estates and the accessibility of the key amenities. Case study Banská Bystrica. Acta Universitatis Lodziensis: Folia Geographica Socio-Oeconomica 30, 51-63. DOI: 10.18778/1508-1117.30.04.

[7] Sander, H. A. \& Polasky, S. (2009). The value of views and open space: Estimates from a hedonic pricing model for Ramsey County, Minnesota, USA. Land Use Policy 26(3). 837845. DOI: 10.1016/j.landusepol.2008.10.009.

[8] Hnilička, P. (2005). Sídelní kaše, Otázky k suburbánní výstavbě rodinných domů. Brno: ERA.

[9] Horňák, M. \& Rochovská, A. (2007). Vybrané aspekty kvality života vo vnútorných perifériích Slovenska. Geographia Cassoviensis 1(1), 55-60.

[10] Hron, P. (1999). Domov - kolébka lidskosti. Púvodní venkovská zástavba v oblasti Jeseníku, její zachováni a rozvoj. Moravský Beroun: Moravská expedice.

[11] Kohout, M., Tichý, D., Tittl, F., Kubánková, J. \& Doležalová, Š. (2016). Sídlište, jak dál? Praha: Czech University of Technology.

[12] Maštálka, M. \& Robová, N. (2016). Občanská vybavenost' jako indikátor kvality života v nové developerské výstavbě. In: Holubec, P., ed., Člověk, stavba a územní plánovaní (pp. 129136). Praha: Czech University of Technology.

[13] Matlovič, R. (2004). Tranzitívna podoba mesta a jeho intraurbánnych štruktúr $v$ ére postkomunistickej transformácie a globalizácie. Sociológia 36(2), 137-158.

[14] Matlovič, R. \& Sedláková, A. (2004). Suburbanizácia transformačný proces priestorovej organizácie postkomunistických miest (empirický príklad Prešova). In Folia Geographica 7 (pp. 75-103). Prešov: Prešovská univerzita.

[15] Melcerová, O. (2012). Uplatnenie polyfunkčnosti pri riešení negatívnych dopadov rezidenčnej suburbanizácie v rámci územia vonkajšieho mesta. In: Intenzita využitia územia slovenských sídel - vybrané otázky (pp. 53-86). Bratislava: Nakladatel'stvo STU.

[16] Nechyba, T. J. \& Walsh, R. P. (2004). Urban sprawl. Journal of Economics Perspectives. 18(4), 177-200. DOI: 10.1257/0895330042632681. 
[17] Newman, P. \& Kenworthy, J. (1989). Cities and Automobile Dependence: An International Sourcebook. Aldershot: Gower Publishing.

[18] Ouředníček, M., Špačková, P. \& Novák, J. (2013). Sub urbs: Krajina, sídla, lidé. Praha: Academia.

[19] Repaská, G., Vilinová, K. \& Šolcová, L. (2017). Trends in development of residential areas in suburban zone of the citiy of Nitra (Slovakia). European Countryside 9(2), 287-301. DOI: 10.1515/euco-2017-0018.

[20] Sopirová, A. (2011). Rezidenčná suburbanizácia a jej odraz vo vidieckych obciach ležiacich v zázemí mesta Bratislavy. In Člověk, stavba a územní plánovaní 5 (pp. 57-65). Praha: Czech University of Technology.

[21] Sopirová, A., Štefancová, L., Bašová, S. \& Görner, K. (2017). Public space and the efficiency of the new residential zones in small slovak towns and villages. European Countryside 9(3), 541-559. DOI: 10.1515/euco-2017-0032.

[22] Stanilov, K. \& Sýkora, L., eds. (2014). Confronting Suburbanization: Urban Decentralization in Postsocialist Central and Eastern Europe. Hoboken, NJ.: Wiley/Blackwell.

[23] Sýkora, L. \& Posová, D. (2011). Formy urbanizace: kritické zhodnocení modelu stadií vývoje měst a návrh alternativní metody klasifikace forem urbanizace. Geografie 116(3), 276-299.

[24] Šilhánková, V. (2003). Veřejné prostory v územně plánovacím procesu. Brno: Vysoké učení technické v Brně.

[25] Štefancová, L. (2013). Urbánna architektúra ako prostriedok udržatel'nosti pre mestá. In Juniorstav 2013 (p. 21). Brno: University of Technology.

[26] Šveda, M. (2016). Život v Bratislavskom suburbiu: prípadová štúdia mesta Stupava. Sociológia 48(2), 139-171.

[27] Šveda, M. (2011). Suburbanizácia v zázemí Bratislavy z hladiska analýzy zmien pokrývky, Geografický časopis 63(2), 155-173.

[28] Tachieva, G. (2011). Sprawl Repair Manual. Washington: Island Press.

[29] Vaishar, A., Vidovićová, L. \& Figueiredo, E. (2018). Quality of Rural Life. European Contryside. 10(2),180-190. DOI: 10.2478/euco-2018-0011.

[30] Vitková, L'. (2008). Kvantitatívne parametre urbanistických štruktúr. Bratislava: Slovak University of Technology.

[31] Vitková, L'. (2015). Metódy hodnotenia verejných priestorov, analýza vybraných námestí Bratislavy. Alfa 20(1), 22-33.

Other sources

[32] AŽ PROJEKT S.R.O. (2010). Štandardy minimálnej vybavenosti obcí. Metodická príručka pre obstarávatel'ov a spracovatel'ov územnoplánovacej dokumentácie. Bratislava: Urbion (update: Ministerstvo životného prostredia SR, 2002).

[33] Buchta, S. (2016). Zlepšovanie kvality života na vidieku. Slovo 16.5.2016.

[34] Buchta, S. (2017). Slovenský vidiek v druhej dekáde 21. storočia. Slovo 21.9.2017.

[35] Jakušová, M. (2010). Diskusia o verejných priestoroch. UzemnePlany. Retrieved from http://www.uzemneplany.sk/sutaz/diskusia-o-verejnych-priestoroch [Acessed 2018-08-3].

[36] Jehlík, J. (2016). Venkov a vesnice. Zlatý řez 39, 14-17.

[37] Sopirová, A. (1996). Územný plán obce Hamuliakovo v znení zmien a doplnkov 2004, 2006, 2007, 2009, 2010, 2012. 
[38] Sopirová, A. (2004). Územný plán obce Kalinkovo v znení zmien a doplnkov 2006, 2007, 2008, 2010.

[39] Sopirová, A. (2008): Územný plán obce Hubice.

[40] Sopirová, A. (2009): Územný plán obce Kvetoslavov v znení zmien a doplnkov 2010-2017.

[41] Sopirová, A. (2009): Územný plán obce Miloslavov v znení zmien a doplnkov 2010-2017.

[42] SB PARTNERS S.R.O. (Balaš, K., Balašová, E., Šebesta, P.) (2001). Územný plán obce Rovinka v znení zmien a doplnkov 2009, 2012, 2014.

[43] Šuška, M., Horký, J., Kostková, L. \& Gogolák, I. (2013). Kysuce, krajina a architektúra cnosti a neresti. Čadca: Bind print.

[44] ÚPn S.R.O. (DUDÁŠOVÁ, M.) (2008). Územný plán obce Dunajská Lužná v znení zmien a doplnkov 2013.

[45] ÚPn S.R.O. (DUDÁŠOVÁ, M.) (2008). Územný plán obce Hviezdoslavov v znení zmien a doplnkov 2014. 